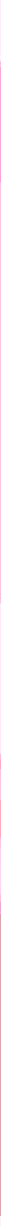

BEATRICE SCHINDLER RANGVID OG MIKKEL LYNGGARD

SPECIALSKOLEELEVERS

RESULTATER VED SKOLE-

GANGENS AFSLUTNING

OG 5 AR SENERE 

Beatrice Schindler Rangvid og Mikkel Lynggaard

\section{Specialskoleelevers resultater ved skolegangens afslutning og fem år senere}

Institut for Uddannelse og Pædagogik (DPU), Aarhus Universitet, 2014 
Titel

Specialskoleelevers resultater ved skolegangens afslutning og fem år senere

Forfattere

Beatrice Schindler Rangvid og Mikkel Lynggaard

Udgiver

Institut for Uddannelse og Pædagogik (DPU)

Aarhus Universitet, 2014

(c) 2014, forfatteren

1. udgave

Kopiering tilladt med tydelig kildeangivelse

Omslag og grafisk tilrettelæggelse:

Knud Holt Nielsen

Forsidefoto:

Colourbox

ISBN

978-87-7684-848-4 (eletronisk udg.)

$978-87-7684-849-1$

$\mathrm{DOI}$

10.7146/aul.34.30 


\section{Indhold}

INDHOLD

2. HVORDAN GÅR DET DE '15-17-ÅRIGE' VED AFSLUTNINGEN AF GRUNDSKOLEN? FAGLIGE

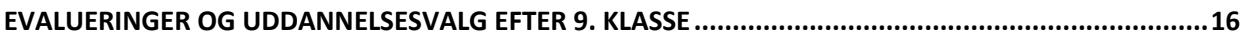

2.1 DeltAgelSE Og PRAeStATIONER I FAgLIGE EVALUERINGER I 8. OG 9. KLASSE ................................................ 17

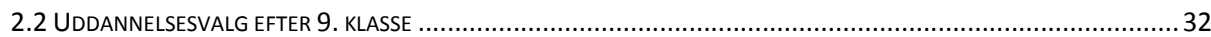

3. 'DE 21-ÅRIGE' FEM ÅR EFTER GRUNDSKOLEN UDDANNELSE, BESKAEFTIGELSE, KRIMINALITET OG

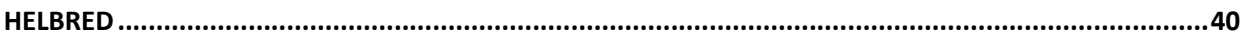

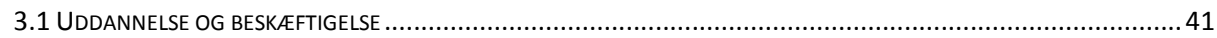

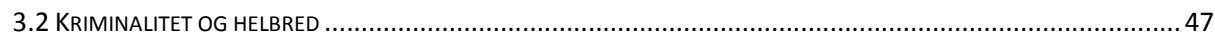

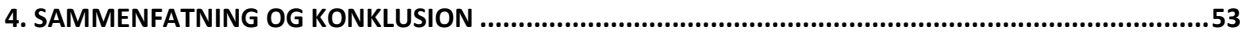

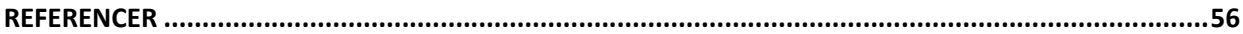





\section{Forord}

Børne- og undervisningsministeriet indgik i december 2012 en aftale om i et forskningsmæssigt samarbejde mellem Aarhus Universitet (Institut for Uddannelse og Pædagogik/forskningsprogrammet SILO) og SFI at gennemføre et projekt, der har til formål at etablere viden om kvalitet på specialskolerne og udvikle kvalitet på skolerne.

Projektet rummer flere dele: Først er der gennemført et review af den internationale forskning om kvalitet på specialskoler, dernæst er der gennemført en survey ved lederne af de danske specialskoler og PPR-enheder. Efterfølgende er der gennemført en registerbaseret analyse af specialskoleelevers resultater af skolegangen. Der er derpå udviklet og afprøvet tre kvalitetsvurderingsværktøjer, og endelig er der beskrevet nogle eksempler på god praksis på danske specialskoler. Der er dermed tale om et meget bredt spektrum af oplysninger om kvalitet på specialskoler, og delene trækker på forskellige metoder, forskningsreview, kvantitative spørgeskemadata, kvantitative registerdata, kvalitative data indsamlet på et seminar og forarbejdet, så de kan anvendes kvantitativt og efterfølgende kvalitativ vurdering og endelig eksempler på god praksis.

De enkelte dele af projektet har hængt sammen på den måde, at reviewet af den internationale forskning sammen med almene demografiske oplysninger og eksisterende kvalitetsindikatorer for folkeskolen har dannet udgangspunkt for konstruktion af de spørgsmål, der indgik i surveyen, samt valget af registerbaserede oplysninger. Med hensyn til eksisterende kvalitetsindikatorer for folkeskolen tænkes på nationale test, afgangsprøver, overgang til ungdomsuddannelse (output). Reviewet har sammen med surveyen og forskellige faglitterære kilder været udgangspunkt for et "fremtidsværksted", der har identificeret kvalitetsindikatorer i specialskoler, som senere er blevet afprøvet og videreudviklet. Det har været centralt for arbejdet med kvalitetsindikatorerne, at de har fokuseret på at forene specialpædagogik og -didaktik med almen pædagogik og didaktik. Registeranalyserne belyser kvalitetsforhold bagudrettet (output), og 


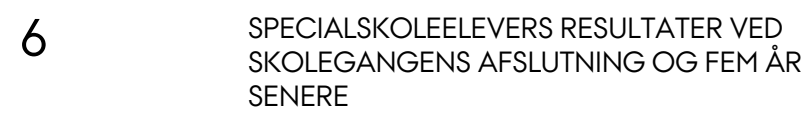

eksemplerne på god praksis kan give inspiration til det fortsatte kvalitetsarbejde på danske specialskoler (proces).

De enkelte dele af projektet er beskrevet i fem rapporter og tre former for kvalitetsudviklingsværktøjer. De fem rapporter er alle udgivet af Institut for Uddannelse og Pædagogik på Aarhus Universitet, hvor de også kan downloades gratis. De tre værktøjer er webbaserede. Følgende giver en oversigt over publikationerne:

Dyssegaard, C.B. og Larsen, M.S. (2014): Kvalitet på specialskoler: En systematisk forskningskortlagning. Dansk Clearinghouse for Uddannelsesforskning. Aarhus Universitet.

Rangvid, B.S. og Egelund, N. (2014): Faktorer af betydning for kvalitet i specialskoler: En survey-kortlegning blandt specialskoler og PPR. SFI.

Rangvid, B.S. og Lynggaard, M. (2014): Specialskoleelevers resultater ved skolegangens afslutning og fem år senere. SFI.

Tetler, S. og Hedegaard-Sørensen, L. (2014): Udvikling af tre kvalitetsudviklingsværktøjer. Redegørelse for baggrund og metode - i forhold til udarbejdelsen af de tre kvalitetsvurderingsskemaer. IUP. Aarhus Universitet.

Morin. A. (2014): Kvalitetsvurdering af undervisningen i specialskoler - Praksisfortællinger. IUP. Aarhus Universitet.

I dette skrift bringes Specialskoleelevers resultater ved skolegangens afslutning og fem år senere.

Niels Egelund, projektleder

Februar 2014 


\section{INDLEDNING}

Specialundervisningsområdet, herunder specialskolerne, er i disse år under store forandringer. Der har endnu ikke været foretaget en omfattende registerundersøgelse af danske specialskolers betydning for elevernes resultater. I denne rapport gennemføres således en kvantitativ analyse af danske specialskoleelevers resultater med hensyn til faglige evaluering, uddannelse, beskæftigelse, kriminalitet og helbred. Formålet med analysen er at komme tættere på en vurdering af kvaliteten af specialskolerne.

Denne delundersøgelse skal ses i sammenhæng med de øvrige dele af Projektet om kvalitet $i$ undervisning på specialskoler, der er gennemført for Ministeriet for Børn og Undervisning i 2013. Hvor indgangsvinklen i de øvrige dele er at vurdere kvalitet i specialskoler ved at sammenligne kvaliteten specialskolerne imellem, så træder denne registerundersøgelse et skridt tilbage og kortlægger specialskolernes resultater med et alternativt undervisningstilbud for elever med særlige behov - folkeskolens specialklasser. Her ser vi således overordnet på undervisningstilbuddet specialskoler som helhed og kortlægger forskelle og ligheder i resultaterne mellem specialskoler og specialklasser

Hovedformålet med denne registerundersøgelse er at gennemføre en første kortlægning af det danske specialundervisningsområde på baggrund af registerdata. Endvidere beregnes korrigerede forskelle i elevernes outcomes i forskellige undervisningsformer. Herved søger vi - såvidt muligt - at tage højde for forskelle mellem elever i forskellige undervisningsformer med det formål at komme en årsagsforklaring af sammenhængen mellem elevernes skolegang og elevernes resultater nærmere.

Der er flere mulige mekanismer, gennem hvilke skolegang på specialskole kan påvirke de unges resultater, sammenlignet med skolegang i en almindelig folkeskole. Først og fremmest kan forskelle mht. kvalitet spille en rolle, men (lave- 
re) forventninger fra både lærere, uddannelsesvejledere og potentielle senere arbejdsgivere kan også spille ind. Endelig kan skolegang på en specialskole på de unges CV måske have en stigmatiserende effekt og kan blive en hindring mhp. at finde beskæftigelse og praktikplads, blive optaget og fastholdt på en uddannelse mv.

Analysen vil bestå af to dele. Første del omhandler en undersøgelse af, hvordan det går eleverne omkring afslutningen af deres skolegang som ca. 15-17-årige. Som 15-17-årige står de unge overfor en række valg, som vil være afgørende for deres senere voksenliv. Nogle vælger at droppe ud af skolen, mens andre vil fortsætte i 10. klasse, produktionsskoleforløb eller lignende. Et andet vigtigt valg i de sidste år i skolen er også, hvorvidt eleverne går op til folkeskolens afgangsprøve, eller om de generelt deltager i de nationale test.

Anden del omhandler en analyse af, hvordan det går eleverne fem år efter 9 . klasse, dvs. som cirka 21-årige. En typisk ung vil fem år senere være færdig med en ungdomsuddannelse og muligvis allerede være i gang med en videregående uddannelse. For elever fra specialskoler kan situationen være anderledes. De har måske gennemført en forberedende uddannelse og kan nu være i gang med en erhvervsuddannelse. Andre er måske ikke kommet meget videre og er på kontanthjælp eller førtidspension. Endelig kan det være, at nogle af de unge er blevet sigtet eller dømt for kriminalitet. Disse forskellige scenarier vil blive analyseret ved hjælp af regressionsanalyser, hvor vi vil se på, om tidligere specialskoleelever har en højere eller lavere risiko for eksempelvis at være registreret med en sigtelse eller dom eller er i gang med en ungdomsuddannelse end lignende elever i folkeskolen (specialklasse). 


\section{DATA OG METODE}

I dette kapitel præsenteres undersøgelsens datamateriale og de statistiske metoder, der anvendes i analyserne.

\subsection{Datamaterialet}

Hovedanalyserne i denne rapport er baseret på registeroplysninger om elever fra 9. klasse-årgangene 2002-2012 i specialskoler og folkeskoler ${ }^{1}$. Til eleverne er knyttet en række oplysninger fra registre, der kan belyse deres egen hhv. familiernes situation i forhold til:

- Demografi

- Socioøkonomi

- Etnicitet

- Somatisk og psykisk sygdom

- Kriminalitet.

Anvendelsen af registerdata giver mulighed for at inddrage en række vigtige faktorer omkring de unge og deres familiebaggrund i analyserne samt at følge de tidligere specialskoleelever frem til deres tidlige voksenalder (21 år) i forhold til en række vigtige udfaldsmål.

\subsection{Sammenligningsgrupper}

Overordnet søger vi at sammenligne specialskoleelever med elever i folkeskolernes specialklasser for at sætte specialskoleelevers undervisningssituation i

\footnotetext{
${ }^{1}$ Skoler i dagbehandlingstilbud og behandlingshjem indgår ikke i analyserne. Endvidere tager nogle elever 9. kl. om enten i samme skole eller fx på efterskole. Kohorter defineres udfra elevens første gang i 9. kl., da anden gang er del af efterfølgende uddannelseshistorie og dermed er outcome.
} 


\section{SPECIALSKOLEELEVERS RESULTATER VED SKOLEGANGENS AFSLUTNING OG FEM ÅR SENERE}

perspektiv. Hvad angår analysen af resultater omkring slutningen af skolegangen, har vi for den relevante årgang direkte oplysninger om, hvem der går i specialklasse, og vi kan derfor eksplicit basere sammenligningen herpå. Hvad angår vore analyser af resultaterne fem år senere, så står en sådan indikator ikke til rådighed, fordi der ikke findes information om specialklassebesøg for de ældre generationer. For på trods af manglen herpå at komme så tæt på dannelsen af den relevante sammenligningsgruppe som muligt, sammenligner vi på en række mål, bl.a. de faglige evalueringer i 8. og 9. klasse ${ }^{2}$.

I de efterfølgende analyser vil den gruppe, vi benævner som "de 15-17-årige", være 9. klasse-årgangen fra sommeren 2012 i folkeskoler eller specialskoler. For disse unge analyserer vi de faglige resultater i slutningen af deres skolegang ved de nationale test i 8 . klasse og afgangsprøverne i 9. klasse samt deres uddannelsesvalg lige efter 9. klasse. Den gruppe, vi benævner som "de 21-årige", er unge i 9. klasse-årgangene fra sommer 2002-2006. Vi observerer disse unge mht. deres resultater fem år efter folkeskolen, når de er omkring 21 år gamle.

Når andet ikke er nævnt, vil den gruppe, vi benævner som specialskoleelever, være gruppen af elever, der på 9. klassetrin går i specialskole. Analysen begrænses af, at elevens institution før 8. klasse ikke er kendt før skoleåret 2007/08 ${ }^{3}$. Det medfører, at det ikke er muligt at inddrage information om, hvor længe elever har gået på specialskolen, da vi for ingen af de elevårgange i vores analyse har information for hele deres skolegang. Endvidere kan elever, som har været indskrevet på en specialskole, men som har forladt den før 8. klasse, ikke identificeres.

I de 9. klasse-årgange, der indgår i vores analyser, er mellem 1 og 2 pct. af alle elever i specialskole, jf. tabel 1.1. I 2002 går 1 pct. af alle elever i specialskole, og i 2011 og 2012 ligger andelen på 1,5 pct.

\footnotetext{
${ }^{2}$ Det ændrer fortolkningen af resultaterne, hvilket beskrives senere, men det er i dette tilfælde nødvendigt for dannelsen af en relevant sammenligningsgruppe.

${ }^{3}$ Langt de fleste (93 pct.), der går i specialskole i 9. klasse, har også gjort det i 8. klasse.
} 
Tabel 1.1. Udviklingen i antallet af specialskoleelever på 9. klassetrin. Antal og procent af alle elever på 9. klassetrin.

\begin{tabular}{|c|c|c|c|c|c|c|c|c|c|c|c|}
\hline $\begin{array}{c}\text { Elever i } \\
\text { specialskole } \\
\text { i 9. klasse }\end{array}$ & $\mathbf{2 0 0 2}$ & $\mathbf{2 0 0 3}$ & $\mathbf{2 0 0 4}$ & $\mathbf{2 0 0 5}$ & $\mathbf{2 0 0 6}$ & $\mathbf{2 0 0 7}$ & $\mathbf{2 0 0 8}$ & $\mathbf{2 0 0 9}$ & $\mathbf{2 0 1 0}$ & $\mathbf{2 0 1 1}$ & $\mathbf{2 0 1 2}$ \\
\hline Antal & 546 & 689 & 737 & 786 & 948 & 757 & 1366 & 984 & 903 & 1024 & 1058 \\
\hline Procent & 1,0 & 1,2 & 1,2 & 1,3 & 1,5 & 1,2 & 2,0 & 1,4 & 1,3 & 1,5 & 1,5 \\
\hline
\end{tabular}

Kilde: Egne beregninger på baggrund af registerdata fra Danmarks Statistik.

En ny datakilde, som vi inddrager i analyserne, er specialundervisningsregistret, som indeholder bl.a. oplysninger om, hvorvidt eleverne modtager specialundervisning i specialskoler, i folkeskolens specialklasser eller i folkeskolens normalklasser. For elevårgangene i vores undersøgelse findes disse oplysninger kun for årgang 2012. Her får næsten 90 pct. ingen specialundervisning, 5,6 pct. får specialundervisning i en normalklasse, mens 3,4 pct. går i specialklasse og 1,5 pct. i specialskole.

I regressionsanalyserne benyttes en række kontrolvariable for at tage højde for, at elever i specialskoler og specialklasser er forskellige mht. en række forhold, som både påvirker deres resultater, og som kan være relateret til deres placering i forskellige undervisningstilbud. Udover et antal variable, der typisk medtages i analyser på uddannelsesområdet ( $f x$ forældrenes uddannelse, tilknytning til arbejdsmarkedet, indkomst; elevens køn, etnicitet, familiestruktur), er der i dette projekt tilknyttet variable, der er særligt relevante for specialundervisningsområdet.

Det nye specialundervisningsregister, som Danmarks Statistik har lanceret fra skoleåret 2011/2012, går i dybden med specialskole og specialklasseelever. Registret indeholder blandt andet informationer om, hvorvidt en elev får specialundervisning i den almindelige folkeskole, går i en specialklasse i folkeskolen eller går på en specialskole. En anden vigtig information fra dette register er 


\section{SPECIALSKOLEELEVERS RESULTATER VED SKOLEGANGENS AFSLUTNING OG FEM ÅR SENERE}

også henvisningsårsagen, der siger noget om, hvorvidt eleven primært har et fysisk handicap eller en given diagnose.

I forbindelse med denne undersøgelse, kan vi således anvende oplysninger om henvisningsårsag til specialundervisning for 9. klasse-årgangen 2012. Den største enkelte henvisningsårsag er generelle indlæringsvanskeligheder, hvilket bl.a. omfatter psykisk udviklingshæmmede, sent udviklede m.fl.. I specialskolerne udgør denne gruppe 27 pct. og i specialklasserne hele 40 pct., jf. tabel 1.2. En anden hyppig henvisningsårsag er udviklingsforstyrrelser (autismespektrum, ADHD mv.) med 13 pct. og 9 pct. i hhv. specialskoler og specialklasser.

Fordelen ved at bruge disse oplysninger i regressionerne er, at man bedre kan tage højde for elevernes type af særlige behov i analyserne. Anvendeligheden af oplysninger om henvisningsårsag begrænses dog af, at 40-50 pct. af eleverne befinder sig i en generel henvisningskategori 'Andet', eller at oplysningen mangler helt. Der er således kun et lille antal elever i de fleste henvisningskategorier. Vi anvender derfor variablen udelukkende som kontrolvariabel i regressionerne, men undlader at lave særlige analyser for enkelte henvisningskategorier.

Således tager vi i regressionerne højde for, om eleven har været i berøring med det psykiatriske system, målt ved Registrering i det psykiatriske forskningsregister i 5-års perioden efter 9. klasse. Desuden medtager vi en variable for, om eleven er blevet anbragt udenfor hjemmet. For ikke at blande årsag og virkning sammen måles disse to forhold i førskolealderen, i regressionerne for resultaterne i slutningen af skolegangen (15-17-årige), mens de i regressionerne, som ser på udfald fem år efter 9. klasse, måles, når eleven er i 9. klasse. 
Tabel 1.2. Henvisningsårsag blandt specialskole- og specialklasseelever. Antal og procent.

\begin{tabular}{|c|c|c|c|c|}
\hline \multirow[t]{2}{*}{ Henvisningsårsag } & \multicolumn{2}{|c|}{ Specialskoler } & \multicolumn{2}{|c|}{ Specialklasser } \\
\hline & Antal elever & Procent & Antal elever & Procent \\
\hline $\begin{array}{l}\text { Generelle indlæringsvanskeligheder (psykisk udviklings- } \\
\text { hæmmede, sent udviklede m.fl.) }\end{array}$ & 277 & 27,0 & 927 & 40,3 \\
\hline $\begin{array}{l}\text { Udviklingsforstyrrelser (autismespektrum, ADHD, damp } \\
\text { m.v.) }\end{array}$ & 129 & 12,6 & 196 & 8,5 \\
\hline $\begin{array}{l}\text { Sociale og miljøbetingede vanskeligheder (adfærdsvanske- } \\
\text { ligheder, socioemotionelle vanskeligheder) }\end{array}$ & 30 & 2,9 & 28 & 1,2 \\
\hline Læse- og skrivevanskeligheder & 18 & 1,8 & 117 & 5,1 \\
\hline Tale- og sprogvanskeligheder & 1 & 0,1 & 26 & 1,1 \\
\hline Hørevanskeligheder (døve og hørehæmmede) & 13 & 1,3 & 6 & 0,3 \\
\hline Synsvanskeligheder (blinde og svagsynede) & 2 & 0,2 & 2 & 0,1 \\
\hline $\begin{array}{l}\text { Bevægelsesvanskeligheder (herunder neurologiske, fx ce- } \\
\text { rebral parese) }\end{array}$ & - & - & 13 & 0,6 \\
\hline $\begin{array}{l}\text { Psykiske vanskeligheder (fx depression, skizofreni, manio- } \\
\text { depression, angst og fobier) }\end{array}$ & - & - & 9 & 0,4 \\
\hline Andet & 377 & 36,8 & 577 & 25,1 \\
\hline Uoplyst & 178 & 17,4 & 397 & 17,3 \\
\hline I alt & 1025 & 100,1 & 2298 & 100 \\
\hline
\end{tabular}

Anm.: På grund af afrunding summerer alle de procentvise angivelser ikke til 100 .

Kilde: Egne beregninger på baggrund af registerdata fra Danmarks Statistik.

\subsection{Metode}

I dette afsnit beskriver vi de statistiske metoder, som vi anvender til at undersøge skolegangen for elever med særlige behov i specialskoler og andre undervisningstilbud (specialklasser).

Indledningsvis anvender vi simple bivariate analyser (chi²-test) eller sammenligning af gennemsnit (t-test). I de statistiske analyser anvendes en lineær (sandsynligheds) regressionsmodel, hvor fejlledene korrigeres for, at vi arbejder med klyngedata. Den lineære regressionsmodel giver ved hjælp af mindste kvadraters metode et bud på, hvor stærk sammenhængen er mellem den forklarende variabel (skolegang i specialskole) og responsvariablen (fx elevernes deltagelse i afgangsprøven). Metoden gør, at man sammenligner elever i specialskoler med elever i andre undervisningstilbud, som ligner dem mest muligt. 


\section{SPECIALSKOLEELEVERS RESULTATER VED SKOLEGANGENS AFSLUTNING OG FEM ÅR SENERE}

For alle udfaldsmål sammenligner vi specialskole- og specialklasseelevernes deltagelse og præstationer ved hjælp af to forskellige typer af lineære regressionsmodeller: henholdsvis med og uden kontrolvariable. I analyserne med kontrolvariable tager vi højde for en række faktorer, som potentielt kan påvirke de sammenhænge, vi ønsker at undersøge isoleret. Hvis resultaterne er forskellige for analyserne henholdsvis med og uden kontrolvariable, henviser det til, at kontrolvariablene både har betydning for elevernes deltagelse og præstationer, og for hvilken skole de går på. Vi kontrollerer blandt andet for forældrenes socioøkonomiske baggrund, da forældrenes baggrund kan have betydning både for elevernes resultater, og om eleverne går i forskellige undervisningstilbud. Endvidere medtages forældrenes tilknytning til arbejdsmarkedet, indkomst samt elevens køn, etnicitet, og familiestruktur. Henvisningsårsag medtages i regressionerne for de 15-17-årige, men haves ikke for de ældre årgange.

I analyserne for de tidligere specialskoleelever fem år efter 9. klasse medtager vi desuden elevernes faglige resultater i slutningen af 9. klasse (deltagelse og præstationer i de nationale test og afgangsprøven). I stedet for at benytte en indikator for, om elever har været i kontakt med det psykiatriske system eller er blevet anbragt udenfor hjemmet i førskolealderen, måler vi her de samme forhold ved afslutningen af skolegangen. Når vi medtager disse ekstra kontroller, selvom de i sig selv til dels måler skolens indflydelse på elevens resultater i 8./9. klasse, er det, fordi der mangler tilstrækkeligt gode kontroller, når vi ikke direkte kan sammenligne med undervisning i specialklasse. Vi må derfor på anden vis søge at skabe et relevant sammenligningsgrundlag. Her må vi benytte elever i folkeskolen, som ligner specialskoleelever mht. fx resultaterne ved de faglige evalueringer som sammenligningsgrundlag.

For fortolkningen af resultaterne for de 21-årige betyder det, at de gælder skolens indflydelse på elevernes resultater som unge voksne, efter de har forladt grundskolen, dvs., at vi estimerer den del af specialskolernes betydning for elevernes 
resultater fem år senere, der ligger udover skolens indflydelse på, hvordan eleverne klarer afgangsprøverne i slutningen af grundskolen ${ }^{4}$.

Trods fordelene ved at kontrollere for en række faktorer, som potentielt kan påvirke og dermed skævvride vores resultater, er det imidlertid vigtigt at understrege, at det ikke er muligt at drage kausale fortolkninger på baggrund af analyseresultaterne. Dette skyldes, at regressionsanalyserne ikke er bedre end summen af de kontrolvariable, der indgår. Hermed er der altid risiko for, at de fundne resultater skyldes faktorer, som det enten ikke er muligt at kontrollere for, eller som vi ikke kan måle godt nok. Selvom det altså ikke er muligt at fortolke årsag-virkningsforhold ud fra analyseresultaterne, forsøger vi altså i analyserne med kontrolvariable at sige noget mere sikkert om betydningen af specialskolegang for elevernes deltagelse og præstationer. Det er i den forbindelse også vigtigt at bemærke, at vi særligt til dette projekt har samlet en omfattende gruppe af kontroller, som er særligt relevant ift. elever med særlige behov (fx henvisningsårsag til specialundervisningen, kontakt til det psykiatriske system, samt anbringelse udenfor hjemmet).

\footnotetext{
${ }^{4}$ Og udover den betydning, skolen måtte have på risikoen for, at eleven kommer i kontakt med det psykiatriske system eller bliver anbragt i løbet af skolegangen.
} 


\section{HVORDAN GÅR DET DE '15-17- ARIGE' VED AFSLUTNINGEN AF GRUNDSKOLEN? Faglige evalueringer og uddannelses- valg efter 9 . klasse}

I dette afsnit ser vi på, hvordan det går specialskoleeleverne som 15-17-årige. I disse sene teenageår er eleverne typisk ved at afslutte deres grundskoleforløb. Hermed står eleverne over for en række valg, som har stor betydning for deres senere voksenliv. Nogle vælger eksempelvis at fortsætte i uddannelsessystemet, mens andre kommer i beskæftigelse eller ender i ledighed.

Resultater fra den internationale forskningslitteratur viser, at elever med særlige behov - forventeligt - har lavere faglige præstationer ${ }^{5}$, samt at disse elever opnår mindre uddannelse ${ }^{6}$. Der er dog ikke enighed om, hvorvidt specialundervisning hjælper, fx finder Hanushek, Kain \& Rivkin (2002), at specialundervisning har positiv effekt på elevernes faglige færdigheder, mens Keslair, Maurin \& McNally (2012) finder, at specialundervisning ingen effekt har.

I dette afsnit undersøger vi først, hvordan det rent fagligt går eleverne lige før, de forlader specialskolen. Herefter kigger vi på perioden lige efter, eleverne har færdiggjort 9. klasse på en specialskole, idet vi her undersøger, hvilke uddannelsesvalg eleverne træffer.

\footnotetext{
${ }^{5}$ Currie \& Stabile (2007); Fletcher \& Wolfe (2008).

${ }^{6}$ Lichtenstein (1987); Wagner \& Blackorby (1996); Zigmond \& Thornton (1985).
} 


\subsection{Deltagelse og prœstationer i faglige evalueringer i 8. og 9. klas-} se

I dette afsnit undersøger vi, hvordan det går eleverne rent fagligt før afslutningen på deres grundskoleforløb på en specialskole. At måle faglighed blandt specialundervisningselever er en udfordring, da kun en mindre del af dem går op til de nationale prøver som afgangsprøverne (FSA) og de nationale test (NT). At eleverne overhovedet tager testene, kan ses som et signal om, at lærerne har vurderet, at eleverne har tilstrækkelig med kvalifikationer til at kunne præstere på et niveau, der nogenlunde svarer til deres alder. Idet mange elever i specialskoler og specialklasser er fritaget fra FSA og NT, ser vi det som et succeskriterium, at eleverne går op til prøverne. På denne baggrund undersøger vi spørgsmålet om specialskoleelevernes faglighed på to måder. Før det første og som det vigtigste - fokuserer vi på, i hvilket omfang specialskoleeleverne overhovedet deltager i faglige evalueringer. I forlængelse heraf ser vi for det andet - og mere sekundært - på, hvordan de deltagende elever rent faktisk præsterer til prøverne.

Specialskoleelevernes deltagelse og præstationer undersøges på to forskellige typer af faglige evalueringer, nemlig (1) de nationale test i 8. klasse og (2) folkeskolens afgangsprøve i 9. klasse. Inden resultaterne fra analyserne præsenteres, gives i det følgende en kortfattet beskrivelse af de to typer af faglige evalueringer, som vi undersøger, samt hvordan vi måler henholdsvis deltagelse og præstationer blandt specialskoleeleverne.

\section{MÅL FOR FAGLIGHED}

\section{De nationale test i 8 . klasse}

Eleverne i folkeskolens almenundervisning skal i løbet af deres skoletid gennemføre 10 obligatoriske nationale test i en række forskellige $\mathrm{fag}^{7}$. De nationale test tester elevernes kundskaber og færdigheder i dele af de pågældende fag, således at lærerne får et bedre indblik i de enkelte elevers faglige niveau. De nationale test er karakteriserede ved at være (1) it-baserede, dvs., eleverne besva-

\footnotetext{
${ }^{7}$ Det er obligatorisk at gennemføre de nationale test i følgende fag: dansk (læsning), matematik, engelsk, geografi, biologi, fysik/kemi.
} 
rer testene på en computer, (2) selvscorende, dvs., elevernes resultater beregnes automatisk via deres besvarelser og (3) adaptive, dvs., testene tilpasses den enkelte elevs niveau undervejs i testforløbet (Ministeriet for Børn og Undervisning, 2013).

I 8. klasse aflægger eleverne i folkeskolens almenundervisning nationale test $\mathrm{i}$ hele fire forskellige prøvediscipliner, nemlig (1) dansk (læsning), (2) geografi, (3) biologi samt (4) fysik/kemi. I alle prøvedisciplinerne testes eleverne inden for tre såkaldte profilområder. Eksempelvis testes eleverne i dansk (læsning) inden for profilområderne sprogforståelse, afkodning og tekstforståelse. For hvert profilområde kan eleverne score fra 0-100 point. Pointskalaen inddeles typisk i fem kategorier, hvor 0-10 point betegnes som "klart under middel", 1135 point betegnes som "under middel", 36-65 point som "middel", 66-90 point som "over middel" og 91-100 som "klart over middel".

Hvad angår specialskoleelevernes deltagelse i de nationale test i 8. klasse definerer vi deltagelse som det at aflægge prøve i mindst én af de fire prøvediscipliner. Omfanget af deltagelsen måles ved andelen af enkeltprøver, som eleverne går op i. Med hensyn til specialskoleelevernes præstationer anvender vi gennemsnittet af scoren for de tre profilområder. Resultaterne fra de tre profilområder vægtes ligeligt.

De nationale test er i udgangspunktet obligatoriske for alle elever, således også for elever med særlige behov. Eleverne kan dog under testforløbet støttes ved, at læreren eller anden støtteperson hjælper eleverne med at orientere sig på opgavesiden, guider dem med stikord eller kort forklarer testopgaven (uden naturligvis derved at give svarene på opgaven $)^{8}$. Resultaterne er derfor ikke nødvendigvis fuldt sammenlignelige med resultaterne for øvrige elever. Tendensen går sandsynligvis i retning af at overvurdere specialundervisningselevers kom-

\footnotetext{
$8 \quad$ Jf. $\quad$ http://www.uvm.dk/Uddannelser/Folkeskolen/De-nationale-test-ogevaluering/Evaluering/Inspiration-til-evaluering/Evaluering-i-folkeskolen-og-elever-medsaerlige-behov
} 
petenceniveau udfra deres testresultater sammenlignet med elever uden særlige behov.

\section{Folkeskolens afgangsprøve i 9. klasse}

Ved udgangen af 9. klasse er der obligatoriske afgangsprøver (FSA) i følgende prøvediscipliner: Dansk (læsning, retskrivning, skriftlig fremstilling og mundtlig), matematik (problemløsning og færdighedsregning), engelsk (mundtlig) samt fysik/kemi (mundtlig). Foruden disse bundne prøvefag udtrækkes der yderligere to prøver til eksamination, ligesom eleverne har mulighed for frivilligt at aflægge prøve i en række valgfag. Vi har af følgende to årsager valgt at fokusere på specialskoleelevernes deltagelse og præstationer i de bundne prøvefag:

For det første fordi de bundne prøvefag anses som folkeskolens kernefag, og samtidig er fagene helt centrale inden for henholdsvis det humanistiske og naturvidenskabelige fagområde. Hermed undersøger vi forskellige typer af akademiske færdigheder hos de specialskoleelever, som deltager i prøverne.

For det andet er karakterne i dansk og matematik - de to nøglefag blandt de bundne prøvefag - særdeles repræsentative for de samlede faglige færdigheder blandt eleverne i almenundervisningen. Således blev det i SFI-rapporten Ledelse, læring og triusel vist, at der eksisterer en statistisk sammenhæng på 0,91 mellem elevernes samlede karaktergennemsnit (hvor alle års- og prøvekarakterer indgår og vægtes ligeligt) og et karaktermål, der baserer sig på en ligelig vægtning af elevernes karakterer i henholdsvis dansk og matematik (Andersen \& Winter , 2011). På denne baggrund vurderer vi, at karaktererne fra de bundne prøvefag er en god indikator for elevernes samlede faglige præstationer.

Parallelt til de nationale test i 8. klasse definerer vi specialskoleelevernes deltagelse i folkeskolens afgangsprøve i 9. klasse, som det at gå op til eksamen i minimum én af prøvedisciplinerne i de bundne prøvefag. Omfanget af deltagelsen måles ved andelen af enkeltprøverne, som eleverne går op i. Elevernes præstati- 


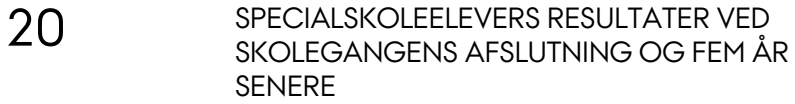

oner måles for hver af prøvedisciplinerne via den karakter, eleverne opnår til prøven på 7-trinsskalaen.

\section{ANALYSERESULTATER: SPECIALSKOLEELEVERNES DELTAGELSE OG PRASTA- TIONER I FAGLIGE EVALUERINGER}

I dette afsnit præsenteres resultaterne fra analyserne af specialskoleelevernes deltagelse og præstationer ved henholdsvis de nationale test i 8. klasse og folkeskolens afgangsprøve i 9. klasse. I analyserne sammenlignes specialskoleelevernes deltagelse og præstationer med elever i folkeskolens specialklasser (se afsnit 1.2 for en nærmere beskrivelse). Endvidere viser vi i tabellerne også deltagelsesfrekvens og faglige præstationer blandt eleverne i folkeskolens normalklasser. Med hensyn til vores sammenligningsgruppe - elever i folkeskolens specialklasser - er det af datamæssige årsager kun muligt at sondre mellem elever i henholdsvis specialklasser og normalklasser for den elev-kohorte, som gik i 9. klasse i skoleåret 2011/12. Derfor er analyserne for de nationale test i 8 . klasse foretaget for skoleåret $2010 / 11^{9}$, mens analyserne for folkeskolens afgangsprøve i 9. klasse omhandler skoleåret 2011/12.

Selvom fokus i dette afsnit er på resultater for de 15-17-årige, giver vi indledningsvis en generel beskrivelse, hvor oplysninger for alle testår og klassetrin indgår.

\section{De nationale test i 8 . klasse}

Vi giver således først en oversigt over, hvordan elever på alle klassetrin har klaret sig i de nationale test (2010-12), jf. tabel 2.1.

\footnotetext{
${ }^{9} \mathrm{Vi}$ ved fra afsnit 1 , at 7 pct. af de elever, der i 9. klasse går i specialskole, ikke har gået der i 8. klasse, hvor de tager de nationale test. Vi har derfor overvejet at køre analyserne uden disse 7 pct., men har besluttet imod det, da vi ikke tilsvarende kan udelade specialklasseelever, der ikke gik i specialklasse i 8. klasse (idet vi ikke har oplysninger om undervisning i specialklasse for året før).
} 
Tabel 2.1. Elevernes deltagelse og gennemsnitsscore ved de nationale test.

\begin{tabular}{|c|c|c|c|c|}
\hline & & $\begin{array}{l}\text { Elever i speci- } \\
\text { alskoler }\end{array}$ & $\begin{array}{l}\text { Elever i speci- } \\
\text { alklasser }\end{array}$ & $\begin{array}{l}\text { Elever i nor- } \\
\text { malklasser }\end{array}$ \\
\hline \multirow[t]{2}{*}{ Alle test } & Deltagelse & $36 \%$ & $44 \%$ & $92 \%$ \\
\hline & Gennemsnitsscore & 36 & 32 & 53 \\
\hline \multirow[t]{2}{*}{$\begin{array}{l}\text { Dansk, læsning, } 2 . \\
\text { klasse }\end{array}$} & Deltagelse & $33 \%$ & $40 \%$ & $92 \%$ \\
\hline & Gennemsnitsscore & 40 & 36 & 54 \\
\hline \multirow[t]{2}{*}{$\begin{array}{l}\text { Dansk, læsning, } 4 . \\
\text { klasse }\end{array}$} & Deltagelse & $36 \%$ & $41 \%$ & $92 \%$ \\
\hline & Gennemsnitsscore & 37 & 29 & 53 \\
\hline \multirow[t]{2}{*}{$\begin{array}{l}\text { Dansk, læsning, } 6 . \\
\text { klasse }\end{array}$} & Deltagelse & $36 \%$ & $47 \%$ & $92 \%$ \\
\hline & Gennemsnitsscore & 35 & 29 & 54 \\
\hline \multirow[t]{2}{*}{$\begin{array}{l}\text { Dansk, læsning, } 8 . \\
\text { klasse }\end{array}$} & Deltagelse & $36 \%$ & $46 \%$ & $88 \%$ \\
\hline & Gennemsnitsscore & 34 & 28 & 54 \\
\hline \multirow[t]{2}{*}{$\begin{array}{l}\text { Matematik, 3. klas- } \\
\text { se }\end{array}$} & Deltagelse & $37 \%$ & $50 \%$ & $92 \%$ \\
\hline & Gennemsnitsscore & 40 & 40 & 52 \\
\hline \multirow[t]{2}{*}{$\begin{array}{l}\text { Matematik, } 6 . \text { klas- } \\
\text { se }\end{array}$} & Deltagelse & $36 \%$ & $50 \%$ & $92 \%$ \\
\hline & Gennemsnitsscore & 33 & 28 & 55 \\
\hline \multirow[t]{2}{*}{ Engelsk, 7. klasse } & Deltagelse & $32 \%$ & $35 \%$ & $90 \%$ \\
\hline & Gennemsnitsscore & 35 & 32 & 53 \\
\hline \multirow[t]{2}{*}{ Biologi, 8. klasse } & Deltagelse & $24 \%$ & $30 \%$ & $87 \%$ \\
\hline & Gennemsnitsscore & 36 & 30 & 50 \\
\hline \multirow[t]{2}{*}{ Geografi, 8. klasse } & Deltagelse & $25 \%$ & $27 \%$ & $87 \%$ \\
\hline & Gennemsnitsscore & 35 & 30 & 49 \\
\hline \multirow[t]{2}{*}{$\begin{array}{l}\text { Fysik/kemi, 8. klas- } \\
\text { se }\end{array}$} & Deltagelse & $23 \%$ & $27 \%$ & $87 \%$ \\
\hline & Gennemsnitsscore & 40 & 36 & 52 \\
\hline
\end{tabular}

Anm.:

Specialskoleelever: Beregninger for skoleårene 2009/10-2011/12.

Specialklasseelever: Beregninger for skoleåret 2011/12.

Normalklasseelever: Beregninger for skoleårene 2009/10-2011/12.

Kilde: Egne beregninger på baggrund af registerdata fra Danmarks Statistik. 
Hvad angår elevernes deltagelse i de nationale test generelt, viser tabel 2.1, at eleverne på specialskoler deltager lidt sjældnere i de nationale test end eleverne i folkeskolens specialklasser. Således fremgår det af tabellen, at 36 pct. af specialskoleeleverne i gennemsnit deltager i de nationale test, mens 44 pct. af eleverne i specialklasserne deltager. Deltagelsesfrekvensen for folkeskoleelever som helhed er 92 pct..

Ser vi på de enkelte test, som eleverne kan deltage i, viser analyserne et ret ensartet deltagelsesmønster. Således deltager både specialskole- og specialklasseeleverne hyppigst i de nationale test i dansk (læsning) og matematik. Her deltager lidt flere end hver tredje af eleverne på specialskoler og 40-50 pct. af eleverne i folkeskolens specialklasser. Med hensyn til de resterende test er deltagelsesfrekvensen generelt lidt lavere. Lavest er deltagelse for testen i fysik/kemi, hvor kun omkring en fjerdedel af specialskole- og specialklasseeleverne deltager.

En barriere i forhold til deltagelse i de nationale test blandt specialskoleelever er muligvis, at de nationale test ikke må tages på andre klassetrin, selvom mange elever i specialundervisningen rent fagligt befinder sig på et niveau, der ligger langt under den alderssvarende. I skoleledersurveyen (Rangvid og Egelund, 2014) blev skolelederne derfor bedt om at vurdere, om de ville fritage færre elever fra alle eller nogle af de nationale test, hvis det var muligt at gennemføre testene på et lavere klassetrin. Blandt alle skoleledere svarede næsten halvdelen bekræftende, mens en tredjedel vurderede, at det ikke ville ændre noget. Hver femte skoleleder kunne ikke vurdere spørgsmålet. Blandt heldagsskolelederne var der større tilslutning end i de almindelige specialskoler til at fritage færre elever, hvis det var muligt at gennemføre testene på et lavere klassetrin. Næsten to tredjedele af skolelederne ville fritage færre elever, og kun knap en fjerdedel vurderede, at de ikke ville fritage færre. Noget tyder derfor på, at deltagelsesfrekvensen kunne øges, hvis man tillod elever at taget tests på andre klassetrin end det alderssvarende. 
Med hensyn til elevernes præstationer i de nationale test i 8. klasse viser analyserne omvendt, at specialskoleeleverne gennemgående klarer sig lidt bedre end eleverne i folkeskolens specialklasser. Således har de deltagende specialskoleelever en gennemsnitlig score på 36 point, hvilket er fire procentpoint mere end de deltagende elever fra specialklasser.

Alt i alt viser analyserne, at eleverne på specialskoler generelt deltager lidt sjældnere i de nationale test end eleverne i folkeskolens specialklasser. Analyserne viser desuden, at denne generelle forskel i deltagelseshyppigheden ikke er drevet af, at specialklasseeleverne deltager oftere i enkelte af de fire nationale test - tværtimod deltager de generelt hyppigere end specialskoleeleverne i alle nationale test.

Årgang 2012 Vender vi blikket mod hovedstikprøven for analyserne af de 1517-årige - 9. klasses elever fra årgang 2012 -- begrænses det anvendte udfaldsmål til de nationale test, som eleverne skal gennemgå i 8. klasse, dvs. mod slutningen af deres skolegang. Som beskrevet tidligere i dette afsnit, har vi dannet en række udfaldsmål til brug for regressionsanalyserne, som er baseret på alle fire obligatoriske test i 8. klasse (dansk/læsning, biologi, geografi, fysik/kemi): deltagelse i testene, andel test taget samt den gennemsnitlige score.

Hvad angår elevernes deltagelse i de nationale test i 8. klasse, viser tabel 2.2, at eleverne på specialskoler med statistisk sikkerhed deltager lidt sjældnere i de nationale test end eleverne i folkeskolens specialklasser. Således fremgår det af tabellen, at 40 pct. af specialskoleeleverne deltager i minimum én af de fire nationale test i 8 . klasse, mens knap halvdelen (46 pct.) af eleverne i specialklasserne tager mindst én af de fire test ${ }^{10}$.

Andelen af test, som eleverne tager, er på omkring 70 pct. for både specialskoler og specialklasser. Med hensyn til elevernes præstationer i de nationale test i 8 . klasse viser analyserne også her, at specialskoleeleverne klarer sig lidt bedre end eleverne i folkeskolens specialklasser. Således har de deltagende special-

\footnotetext{
${ }^{10}$ Bemærk, at tallene ikke svarer helt til tallene i tabel 2.1, bl.a. fordi vi her kun ser på én årgang af elever - 9. klassetrin i 2012 - og kun på NT på 8. klassetrin.
} 
skoleelever en gennemsnitlig score på 35 point, hvilket er fem procentpoint mere end de deltagende elever fra specialklasser.

Opsummerende viser analyserne vedrørende de nationale test i 8. klasse for årgang 2012, at specialskoleeleverne på den ene side deltager sjældnere i testene end specialklasseeleverne, men at de deltagende specialskoleelever på den anden side præsterer bedre end de deltagende elever fra folkeskolens specialklasser. I næste afsnit undersøges det, hvorvidt de fundne forskelle også gør sig gældende for en anden type af faglig evaluering, nemlig folkeskolens afgangsprøve i 9 . klasse.

Tabel 2.2. Elevernes deltagelse og gennemsnitsscore ved de nationale test $i$ 8. klasse $i$ skoleåret 2010/11 (9. klasses årgang 2012)

\begin{tabular}{|c|l|c|c|c|c|}
\hline \multicolumn{2}{|c|}{} & $\begin{array}{c}\text { Elever i special- } \\
\text { skoler }\end{array}$ & $\begin{array}{c}\text { Elever i speci- } \\
\text { alklasser }\end{array}$ & $\begin{array}{c}\text { Forskel ml. special- } \\
\text { skole- og special- } \\
\text { klasseelever }\end{array}$ & $\begin{array}{c}\text { Elever i nor- } \\
\text { malklasser }\end{array}$ \\
\hline I alt & Deltagelse & $40 \%$ & $46 \%$ & $* * *$ & $97 \%$ \\
\hline & Andel prøver taget & $71 \%$ & $70 \%$ & & $96 \%$ \\
\hline & Gennemsnitsscore & 35 & 30 & $* * *$ & 51 \\
\hline
\end{tabular}

Anm.: । 8. klasse omfatter de nationale test følgende prøvediscipliner: Dansk (læsning), biologi, geografi og fysik/kemi.

Specialskoleelever: $\mathrm{N}=1127$ (deltagelse) og 425 (gennemsnitsscore)

Specialklasseelever: $\mathrm{N}=1953$ (deltagelse) og 846 (gennemsnitsscore)

Kilde: Egne beregninger på baggrund af registerdata fra Danmarks Statistik.

\section{Folkeskolens afgangsprøve i 9. klasse}

Selvom fokus i dette afsnit er på elevernes resultater i 15-17 års alderen, så er det interessant indledningsvis at se på elevernes deltagelsesfrekvens i folkeskolens afgangsprøve tilbage til 2002, hvor disse tal blev offentliggjort for første gang. Figur 2.1 viser deltagelsesfrekvensen for elever i specialskoler og folkeskoler $^{11}$. Selvom andelen af deltagende elever fra specialskoler på omkring 30 pct. i de seneste år kan forekomme lav, er det imidlertid værd at bemærke, at deltagelsesfrekvensen har været stigende gennem det sidste årti, hvor andelen

\footnotetext{
11 Vi nøjes med at medtage kernefagene dansk og matematik, når vi ser på hele årrækken, da der har været ændringer i viften af prøvefagene undervejs.
} 
af deltagende specialskoleelever er steget fra ca. 10 pct. i 2002 til knap 30 pct. i 2012. Udviklingen viser altså, at en stadigt større andel af eleverne i specialskoler i et vist omfang deltager i de afsluttende prøver i 9. klasse.

Ved folkeskolens afgangsprøve i 9. klasse er specialskoleelevernes deltagelsesfrekvens - parallelt til de nationale test i 8. klasse - med statistisk sikkerhed lavere end deltagelsen blandt eleverne i folkeskolens specialklasser. Resultatet fremgår af tabel 2.3, som viser, at 29 pct. af specialeskoleeleverne deltager i minimum ét af de bundne prøvefag ved afgangsprøverne i 9. klasse, mens 38 pct. af eleverne i specialklasserne deltager. Endvidere ses det af tabellen, at de deltagelsesmæssige forskelle er relativt konsistente på tværs af de enkelte bundne prøvefag. Således deltager specialskoleeleverne med statistisk sikkerhed sjældnere i både dansk ${ }^{12}$, matematik og fysik/kemi, imens der dog ikke med sikkerhed er forskel på elevernes deltagelseshyppighed for afgangsprøven i engelsk.

${ }^{12}$ Forskellen med hensyn til dansk er hovedsageligt drevet af lavere deltagelse af specialskoleelever i dansk (læsning). 


\section{SPECIALSKOLEELEVERS RESULTATER VED SKOLEGANGENS AFSLUTNING OG FEM ÅR SENERE}

Figur 2.1: Deltagelse i folkeskolens afgangsprøver (9. kl. årgangene 2002-2012)

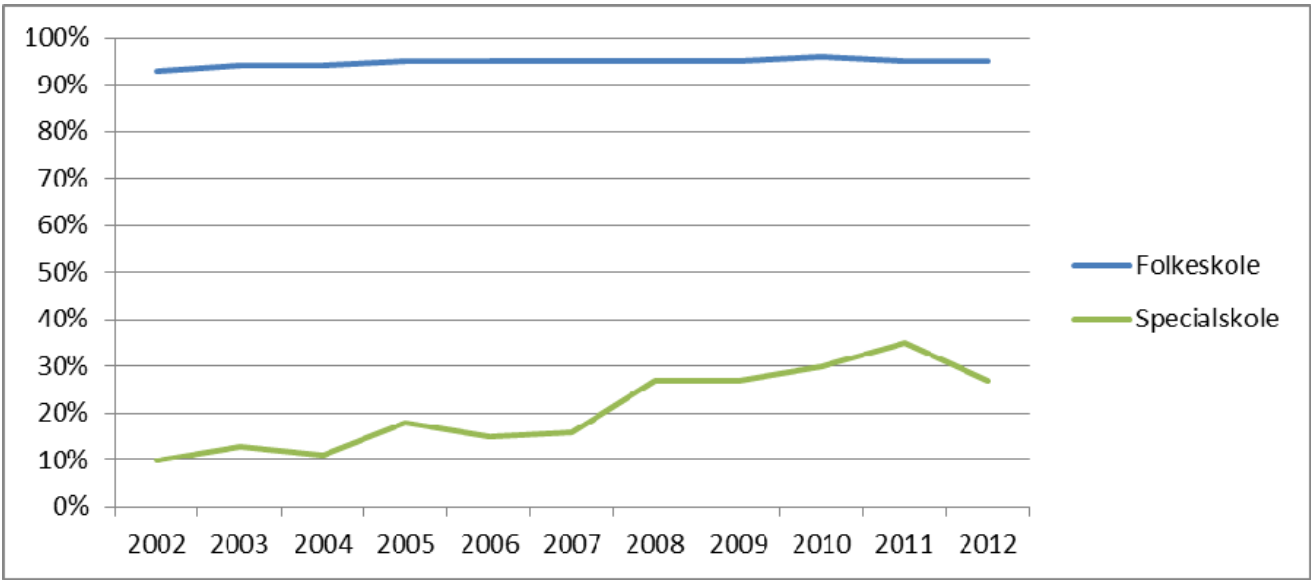

Hvad angår omfang af deltagelse i FSA viser tabel 2.3, at hvor specialskoleelever mindre hyppigt deltager i FSA, så går de deltagende elever op til et større antal prøver. Specialskoleelever går i gennemsnit op til 64 pct. af de bundne prøver, sammenlignet med specialklasseelevernes 58 pct..

Også med hensyn til specialskoleelevernes præstationer i folkeskolens afgangsprøve finder vi resultater, der er parallelle til præstationerne i de nationale test $\mathrm{i}$ 8. klasse. De deltagende specialskoleelever klarer sig nemlig bedre end gruppen af specialklasseelever, som går op i mindst et af de bundne prøvefag. Med en gennemsnitskarakter på 4,9 er specialskoleelevernes gennemsnitlige score 0,6 procentpoint højere end eleverne fra specialklassers.

Sammenfattende viser analyserne - både med hensyn til de nationale test i 8 . klasse og folkeskolens afgangsprøve i 9. klasse - at specialskoleeleverne generelt deltager sjældnere $\mathrm{i}$ faglige evalueringer end eleverne $\mathrm{i}$ folkeskolens specialklasser. Til gengæld klarer de deltagende specialskoleelever sig bedre rent præstationsmæssigt end de deltagende specialklasseelever. Hvad angår omfang af deltagelse, så går specialskoleeleverne op til flere prøver ved FSA end speci- 
alklasseeleverne, mens der ikke er forskel på omfang af deltagelse mht. de nationale test. 
Tabel 2.3. Elevernes deltagelse og karakterer ved folkeskolens afgangsprøve i skoleåret 2011/12.

\begin{tabular}{|c|c|c|c|c|c|}
\hline & & $\begin{array}{l}\text { Elever i spe- } \\
\text { cialskoler }\end{array}$ & $\begin{array}{l}\text { Elever i speci- } \\
\text { alklasser }\end{array}$ & $\begin{array}{c}\text { Forskel ml. } \\
\text { specialskole- } \\
\text { og specialklas- } \\
\text { seelever }\end{array}$ & $\begin{array}{l}\text { Elever i nor- } \\
\text { malklasser }\end{array}$ \\
\hline \multirow[t]{3}{*}{ I alt } & Deltagelse & $29 \%$ & $38 \%$ & $* * *$ & $98 \%$ \\
\hline & $\begin{array}{l}\text { Andel prøver } \\
\text { taget }\end{array}$ & $64 \%$ & $58 \%$ & $* *$ & $99 \%$ \\
\hline & Karakterer & 4,9 & 4,3 & $* *$ & 6,7 \\
\hline \multirow[t]{3}{*}{ Dansk, i alt } & Deltagelse & $26 \%$ & $32 \%$ & $* * *$ & $98 \%$ \\
\hline & $\begin{array}{l}\text { Andel prøvet } \\
\text { taget }\end{array}$ & $83 \%$ & $77 \%$ & $* *$ & $99 \%$ \\
\hline & Karakterer & 4,7 & 4,0 & $* * *$ & 6,8 \\
\hline \multirow[t]{2}{*}{ Dansk, læsning } & Deltagelse & $25 \%$ & $30 \%$ & $* *$ & $97 \%$ \\
\hline & Karakterer & 5,0 & 4,3 & $* *$ & 6,6 \\
\hline \multirow[t]{2}{*}{ Dansk, retskrivning } & Deltagelse & $24 \%$ & $27 \%$ & & $97 \%$ \\
\hline & Karakterer & 4,1 & 3,4 & $* * *$ & 6,6 \\
\hline \multirow[t]{2}{*}{ Dansk, skriftlig fremstilling } & Deltagelse & $19 \%$ & $22 \%$ & & $97 \%$ \\
\hline & Karakterer & 4,1 & 3,5 & $*$ & 6,4 \\
\hline \multirow[t]{2}{*}{ Dansk, mundtlig } & Deltagelse & $17 \%$ & $18 \%$ & & $96 \%$ \\
\hline & Karakterer & 6,3 & 5,8 & & 7,5 \\
\hline \multirow[t]{3}{*}{ Matematik, i alt } & Deltagelse & $21 \%$ & $30 \%$ & $* * *$ & $97 \%$ \\
\hline & $\begin{array}{l}\text { Andel prøver } \\
\text { taget }\end{array}$ & $88 \%$ & $85 \%$ & & $100 \%$ \\
\hline & Karakterer & 4,4 & 4,1 & & 6,7 \\
\hline \multirow[t]{2}{*}{ Matematik, færdighedsregn. } & Deltagelse & $21 \%$ & $30 \%$ & $* * *$ & $97 \%$ \\
\hline & Karakterer & 5,2 & 4,8 & & 7,1 \\
\hline \multirow[t]{2}{*}{ Matematik, problemløsning } & Deltagelse & $16 \%$ & $21 \%$ & $* *$ & $97 \%$ \\
\hline & Karakterer & 3,4 & 3,3 & & 6,4 \\
\hline \multirow[t]{2}{*}{ Engelsk, mundtlig } & Deltagelse & $15 \%$ & $16 \%$ & & $96 \%$ \\
\hline & Karakterer & 6,7 & 6,6 & & 7,4 \\
\hline \multirow[t]{2}{*}{ Fysik, kemi } & Deltagelse & $10 \%$ & $13 \%$ & $* *$ & $95 \%$ \\
\hline & Karakterer & 5,9 & 5,3 & & 6,3 \\
\hline
\end{tabular}

Anm.: ${ }^{* *} \mathrm{p}<0,001,{ }^{* *} \mathrm{p}<0,01$ og $* \mathrm{p}<0,05$. T-test er anvendt, og stjernerne indikerer signifikante forskelle mellem eleverne i henholdsvis specialskoler og specialklasser. Specialskoleelever: $\mathrm{N}=1127$ (deltagelse) og 326 (karakterer) Specialklasseelever: $\mathrm{N}=1953$ (deltagelse) og 738 (karakterer)

Kilde: Egne beregninger på baggrund af registerdata fra Danmarks Statistik. 


\section{BETYDNINGEN AF SKOLEGANG PÅ SPECIALSIKOLE FOR DELTAGELSE OG PRASTATIONER I FAGLIGE EVALUERINGER}

Selvom deltagelse i både NT og FSA som udgangspunkt er obligatorisk for alle elever, bliver mange elever på specialskoler eller i specialklasser fritaget, fordi deres faglige niveau er for lavt, eller deres psykiske og somatiske vanskeligheder er for omfattende.

I dette afsnit forsøger vi at tage høje for nogle af de systematiske forskelle mellem eleverne, som kan tænkes at have betydning for deres deltagelse og præstationer $\mathrm{i}$ de to undersøgte typer af faglige evalueringer. Formålet med at tage højde for disse andre faktorers betydning for elevernes deltagelse og præstationer er, at vi hermed kan sige noget mere præcist om, hvorvidt elevernes skolegang på en specialeskole faktisk har betydning for (1) hvor mange elever der deltager - og i hvilket omfang, og (2) hvor godt eleverne klarer sig.

\section{Specialskoleelevernes deltagelse i faglige evalueringer}

I tabel 2.4. ses resultaterne for analyserne af elevernes deltagelse i de nationale test i 8. klasse og folkeskolens afgangsprøve i 9. klasse. Hvad angår de nationale test i 8. klasse viser tabellen, at der ikke er forskel på specialskole- og specialklasseelevernes deltagelseshyppighed - hverken med eller uden kontrolvariable. Resultatet uden kontrolvariable er modsat det ellers tilsvarende estimat i tabel 2.3. ikke statistisk sikkert ${ }^{13}$. Det vil sige, at når vi i regressionen tager højde for datastrukturen, så er deltagelsesfrekvensen for elever i specialklasser ikke (med statistisk sikkerhed) større end for elever i specialskoler.

Derimod viser tabellen, at der er forskel på andelen af elever på henholdsvis specialskoler og specialklasser, som deltager i folkeskolens afgangsprøve. Forskellene er statistisk sikre både med og uden kontrolvariable. Minustegnet henviser til, at specialskoleelevernes sandsynlighed for at deltage i afgangsprøverne er lavere end specialklasseelevernes - hvilket altså stadig er tilfældet, når vi

\footnotetext{
${ }^{13}$ Forskellen skyldes, at vi i regressionerne kan tage højde for, at restleddene for eleverne inden for samme skole kan være korrelerede (såkaldte klynger). Denne korrektion er relevant, men har tendens til at øge den beregnede usikkerhed for estimatet, hvilket gør, at resultatet ikke længere er statistisk sikkert forskelligt fra nul.
} 
har taget højde for en række observerbare forskelle mellem eleverne $\mathrm{i}$ de to grupper. Eftersom der stadig er deltagelsesmæssige forskelle efter kontrol for baggrundsfaktorernes betydning, tyder resultaterne på, at det at gå på en specialskole (i forhold til en specialklasse) er forbundet med lavere sandsynlighed for at deltage i folkeskolens afgangsprøver.

Hvad angår omfang af deltagelse målt ved, hvor stor en del af prøver/test de deltagende elever går op $i$, er der ikke statistisk sikker forskel mellem elever i specialskole og specialklasse. 
Tabel 2.4. Betydningen af skolegang på specialskole for deltagelse og præstationer ved de nationale test $i$ 8. klasse og folkeskolens afgangsprøve.

\begin{tabular}{|l|c|c|c|c|}
\hline \multirow{2}{*}{} & \multicolumn{2}{|c|}{ Nationale test i 8. klasse } & \multicolumn{2}{c|}{ Folkeskolens afgangsprøve } \\
\cline { 2 - 5 } & $\begin{array}{c}\text { Uden kontrol- } \\
\text { variabler }\end{array}$ & $\begin{array}{c}\text { Med kontrolva- } \\
\text { riabler }\end{array}$ & $\begin{array}{c}\text { Uden kontrolva- } \\
\text { riabler }\end{array}$ & $\begin{array}{c}\text { Med kontrolva- } \\
\text { riabler }\end{array}$ \\
\hline Deltagelse & - & - & $\bullet \div$ & $\div$ \\
\hline Andel prøver taget & - & - & - & - \\
\hline Præstationer & + & - & + & - \\
\hline
\end{tabular}

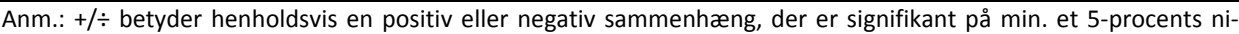
veau.

- betyder ingen sammenhæng.

Deltagelse: $\mathrm{N}=3080$ (både nationale test i 8 . klasse og folkeskolens afgangsprøve)

Andel prøver taget: $\mathrm{N}=1271$ (nationale test i 8. klasse) og 1064 (folkeskolens afgangsprøve)

Præstationer: $\mathrm{N}=1271$ (nationale test i 8. klasse) og 1064 (folkeskolens afgangsprøve)

Kilde: Egne beregninger på baggrund af registerdata fra Danmarks Statistik.

\section{Specialskoleelevernes prœstationer ved de faglige evalueringer}

Hvad angår specialskoleelevernes faglige præstationer genfinder vi i analyserne uden kontrolvariable resultaterne fra tabel 2.2. og 2.3., som gav et mere detaljeret indblik i elevernes præstationer for de enkelte prøvefag ved 9. klasseafgangsprøven og de enkelte test i de nationale test i 8. klasse. Således viser det positive fortegn i analyserne uden kontrolvariable, at de deltagende specialskoleelever med statistisk sikkerhed klarer sig bedre til prøverne end de deltagende elever fra specialklasser.

Denne positive sammenhæng mellem specialskolegang og elevpræstationer relativt til specialklasseelever - forsvinder imidlertid, når vi tager højde for forskelle i elevernes baggrundskarakteristika. Selvom fortegnet stadig er positivt for analyserne med kontrolvariable, er sammenhængen ikke længere statistisk signifikant.

Vi har desuden gennemført analysen for resultaterne ved 9. klasseafgangsprøven, hvor vi som en ekstra kontrol har medtaget resultaterne fra de nationale test i 8 . klasse, uden at det dog ændrer konklusionen. 


\subsection{Uddannelsesvalg efter 9. klasse}

I forlængelse af undersøgelsen af specialskoleelevernes faglige præstationer før de forlader 9. klasse, kigger vi i dette afsnit på, hvilke uddannelsesvalg eleverne foretager, efter de har afsluttet 9. klasse på en specialskole.

Ligesom i de foregående afsnit sammenligner vi også i dette afsnit specialskoleeleverne med elever fra folkeskolens specialklasser. Først undersøger vi, hvilke uddannelsesvalg specialskoleeleverne træffer efter 9. klassetrin, og om der er forskel på specialskole- og specialklasseelevernes uddannelsesvalg. Herefter undersøger vi, hvad skolegang på en specialskole betyder for de uddannelsesvalg, eleverne træffer efter 9. klasse. Inden resultaterne fra analyserne præsenteres, giver vi i næste afsnit en kortfattet beskrivelse af de mål for uddannelsesvalg, vi fokuserer på i analyserne.

\section{MÅL FOR UDDANNELSESVALG}

Fra januar 2011 har UNI-C lanceret et nyt register - Ungedatabasen - som giver et samlet overblik over unges uddannelses- og beskæftigelsesstatus. Ungedatabasen er baseret på fortløbende udtræk om uddannelses- og beskæftigelsesaktiviteter fra administrative systemer i kommuner, uddannelsesinstitutioner, UUcentrene, e-indkomstregisteret, m.fl. Ungedatabasen var på det tidspunkt, hvor projektets datasæt blev samlet (august 2013), opdateret med oplysninger frem til maj 2013 (men hvor 2013-tallene er foreløbige, som endnu ikke er publiceret). En fordel ved det ny register er således, at det er betydeligt mere aktuelt end de øvrige registre, hvorfor vi for de helt nye årgange af 9. klasse-elever allerede nu har oplysninger om, hvilken uddannelse de har valgt året efter 9. klasse. Med det nye register er det således muligt at lave et betydeligt hurtigere opdateret billede af de unges valg og fravalg fra 15-års alderen. Denne hurtige opdatering kommer dog til dels på bekostning af, at de nyere tal i databasen endnu ikke har gennemgået samme kvalitetssikring som de øvrige registerdata. Dette kan medføre flere målefejl, og generelt set vil analysen derfor være behæftet med flere målefejl, end vi ellers ville forvente ${ }^{14}$.

\footnotetext{
${ }^{14}$ En fejl i det nye register, der kom frem undervejs i arbejdet med data for dette projekt, var, at en betydelig del af elever på specialskoler if. kodningen i registeret går i 9. klasse to år i træk.
} 
Ungedatabasen indeholder følgende oplysninger for unge 15-17-årige:

- Antal unge, der er i gang med en ordinær uddannelse (grundskole, ungdomsuddannelse og videregående uddannelse)

- Antal unge, der er i gang med forskellige forberedende aktiviteter mv.

- Antal unge, der ikke er i uddannelse, beskæftigelse mv.

Som det vil fremgå senere i dette afsnit, er det ikke muligt at arbejde med meget detaljerede udfaldsmål i den statistiske analyse, da fordelingen af elever på uddannelsesvalg og beskæftigelse er koncentreret i enkelte kategorier. Der er derfor kun meget få observationer på specialskoleelever i de fleste enkelte kategorier af uddannelsesvalg.

Mens vi indledningsvis fremlægger de unges uddannelsesvalg på enkelte kategorier for at give et detaljeret billede af elevernes status det første år efter 9 . klasse, må vi danne nogle meget brede kategorier til den efterfølgende statistiske undersøgelse. På baggrund af de begrænsede muligheder har vi valgt følgende to udfaldsmål, som begge måles i slutningen ${ }^{15}$ af elevernes første år efter 9. klasse:

- I gang med en (almindelig) ungdomsuddannelse

- I gang med en uddannelse (inkl. forberedende forløb + 10. kl.).

\section{ANALYSERESULTATER: SPECIALSKOLEELEVERNES UDDANNELSESVALG EFTER 9. KLASSE}

Tabel 2.5. viser specialskoleelevernes uddannelsesvalg henholdsvis et og to år efter, at eleverne afsluttede 9. klasse. Overordnet set sondres der i tabellen imellem fire forskellige typer af uddannelsesvalg efter 9. klasse, nemlig (1) om ele-

UNI-C har oplyst, at de ikke modtager klassetrinsoplysninger fra specialskoler til Ungedatabasen - og klassetrinet er derfor mekanisk blevet kodet til 9. klasse. Et tjek af data op mod KOETregistret viste, at de fleste af disse elever, der if. Ungedatabasen gik i 9. klasse to år i træk, faktisk gik i 10. klasse if. KOET. Til brug for analyserne i dette projekt, er koden for disse elever derfor blevet ændret til 10. klasse.

${ }^{15}$ Helt konkret er status for vores udfaldsmål målt i maj måned. 


\section{SPECIALSKOLEELEVERS RESULTATER VED SKOLEGANGENS AFSLUTNING OG FEM ÅR SENERE}

verne fortsætter i 10. klasse, (2) om eleverne deltager i forberedende aktiviteter til en ungdomsuddannelse, (3) om eleverne er i gang med en ungdomsuddannelse, eller (4) om eleverne hverken er i uddannelse eller beskæftigelse.

Som det fremgår af tabellen, fortsætter mere end fire ud af fem (81 pct.) af specialskoleeleverne i 10. klasse året efter, at de har færdiggjort 9. klasse. Dette er en lidt større andel end specialklasseeleverne, hvor tre ud af fire (75 pct.) elever fortsætter i 10. klasse. Med hensyn til de øvrige uddannelsesvalg viser tabellen, at der er henholdsvis 7 pct. af specialskoleeleverne, som deltager $\mathrm{i}$ forberedende aktiviteter, og som er i gang med en egentlig ungdomsuddannelse. Til sammenligning er andelen af specialklasseelever en smule højere for begge uddannelsesvalg, idet 10 pct. af eleverne fra specialklasserne begynder på forberedende aktiviteter mens 12 pct. starter på en ungdomsuddannelse. Endelig fremgår det af tabellen, at det blot er 4 pct. af specialskole- og specialklasseeleverne, som et år efter afslutningen af 9. klasse hverken er under uddannelse eller i beskæftigelse. 
Tabel 2.5. Elevernes uddannelsesvalg henholdsvis et og to år efter 9. klasse.

\begin{tabular}{|c|c|c|c|c|c|c|c|}
\hline & \multicolumn{6}{|c|}{ et år efter 9. klasse } & \multirow{3}{*}{$\begin{array}{c}\begin{array}{c}\text { to år efter } 9 . \\
\text { klasse }\end{array} \\
\begin{array}{c}\text { Elever i speci } \\
\text { alskoler }\end{array} \\
\text { Procent } \\
\end{array}$} \\
\hline & \multicolumn{2}{|c|}{$\begin{array}{l}\text { Elever i specialsko- } \\
\text { ler }\end{array}$} & \multicolumn{2}{|c|}{$\begin{array}{l}\text { Elever i specialklas- } \\
\text { ser }\end{array}$} & \multicolumn{2}{|c|}{$\begin{array}{l}\text { Elever i normal- } \\
\text { klasser }\end{array}$} & \\
\hline & Antal & Procent & Antal & Procent & Antal & Procent & \\
\hline Grundskole (10. klasse) & 886 & $81 \%$ & 1392 & $75 \%$ & 20969 & $49 \%$ & $18 \%$ \\
\hline Forberedende aktiviteter & 78 & $7 \%$ & 184 & $10 \%$ & 2060 & $5 \%$ & $26 \%$ \\
\hline Forberedende uddannelse & - & - & - & - & - & - & - \\
\hline 10.-13. skoleår & 2 & $<1 \%$ & 6 & $<1 \%$ & 21 & $<1 \%$ & $1 \%$ \\
\hline$\varnothing$ vrige forløb & 4 & $<1 \%$ & 18 & $1 \%$ & 70 & $<1 \%$ & $1 \%$ \\
\hline Adgangsgivende undervisning & 1 & $<1 \%$ & 1 & $<1 \%$ & 33 & $<1 \%$ & $3 \%$ \\
\hline Voksenundervisning & 4 & $<1 \%$ & 4 & $<1 \%$ & 10 & $<1 \%$ & $1 \%$ \\
\hline Produktionsskoler & 32 & $3 \%$ & 98 & $5 \%$ & 589 & $1 \%$ & $7 \%$ \\
\hline Andet & - & - & - & - & - & - & - \\
\hline $\begin{array}{l}\text { Andre udviklende og forberedende aktivi- } \\
\text { teter }\end{array}$ & 23 & $2 \%$ & 33 & $2 \%$ & 853 & $2 \%$ & $4 \%$ \\
\hline Midlertidige aktiviteter & 6 & $1 \%$ & 12 & $1 \%$ & 106 & $<1 \%$ & $3 \%$ \\
\hline Beskæftigelse mv.(over 18 timer/uge) & 6 & $1 \%$ & 12 & $1 \%$ & 367 & $1 \%$ & $6 \%$ \\
\hline Ungdomsuddannelse & 75 & $7 \%$ & 218 & $12 \%$ & 20990 & $44 \%$ & $49 \%$ \\
\hline \multicolumn{8}{|l|}{ Gymnasiale uddannelser } \\
\hline STX & 2 & $<1 \%$ & 8 & $<1 \%$ & 11313 & $26 \%$ & $1 \%$ \\
\hline $\mathrm{HF}$ & - & - & - & - & 20 & $<1 \%$ & $1 \%$ \\
\hline Studenterkursus & - & - & - & - & - & - & - \\
\hline IB (international STX) & - & - & - & - & 71 & $<1 \%$ & - \\
\hline $\mathrm{HHX}$ & 1 & $<1 \%$ & - & - & 2605 & $6 \%$ & $<1 \%$ \\
\hline HTX & 2 & $<1 \%$ & 3 & $<1 \%$ & 1728 & $4 \%$ & $1 \%$ \\
\hline \multicolumn{8}{|l|}{ Erhvervsfaglige uddannelser } \\
\hline Erhvervsuddannelser & 36 & $3 \%$ & 145 & $8 \%$ & 3301 & $8 \%$ & $13 \%$ \\
\hline$\varnothing$ vrige erhvervsfaglige uddannelser & 5 & $<1 \%$ & 23 & $1 \%$ & 36 & $<1 \%$ & $2 \%$ \\
\hline Andre ungdomsuddannelser & - & - & - & - & - & - & - \\
\hline Særligt tilrettelagt ungdomsudd. & 29 & $3 \%$ & 39 & $2 \%$ & 9 & $<1 \%$ & $30 \%$ \\
\hline Ikke i uddannelse, beskæftigelse mv. & 47 & $4 \%$ & 70 & $4 \%$ & 773 & $2 \%$ & $6 \%$ \\
\hline Arbejde under 18 timer/ugen & 8 & $1 \%$ & 17 & $1 \%$ & 296 & $1 \%$ & $1 \%$ \\
\hline \multicolumn{8}{|l|}{$\underline{\text { Uden aktivitet og off. fors } \varnothing \text { rgelse }}$} \\
\hline Under 1 måned & 2 & $<1 \%$ & 6 & $<1 \%$ & 80 & $<1 \%$ & $<1 \%$ \\
\hline 1 til 2 måneder & - & - & 5 & $<1 \%$ & 40 & $<1 \%$ & $<1 \%$ \\
\hline 2 til 3 måneder & 1 & $<1 \%$ & 1 & $<1 \%$ & 31 & $<1 \%$ & $<1 \%$ \\
\hline Over 3 måneder & 31 & $3 \%$ & 35 & $2 \%$ & 310 & $1 \%$ & $3 \%$ \\
\hline Antal elever & 1090 & & 1869 & & 42953 & & 1012 \\
\hline
\end{tabular}

Anm: Beregningerne et år efter 9. klasse er foretaget for elever, som gik i 9. klasse i skoleåret 2011/12. Beregningerne to år efter 9 . klasse er foretaget for elever, som gik i 9 . klasse i skoleåret 2010/11. 
Fokuserer man på udviklingen i specialskoleelevernes uddannelsesvalg over tid (i stedet for at sammenligne dem med specialklasseeleverne et år efter 9. klasse), viser tabellen, at langt flere specialskoleelever er i gang med en ungdomsuddannelse to år efter 9 . klasse ${ }^{16}$ end ét år efter 9. klasse. Som det fremgår af tabellen, er næsten halvdelen (49 pct.) af specialskoleeleverne i gang med en ungdomsuddannelse to år efter, de har forladt 9. klasse, mens det kun var 7 pct. af eleverne, der gik i gang med en ungdomsuddannelse lige efter 9. klasse. Kigger man nærmere på de enkelte typer af ungdomsuddannelser, viser tabellen, at det hovedsageligt er de "særligt tilrettelagte ungdomsuddannelser" (30 pct.) og "erhvervsuddannelser" (13 pct.), som eleverne fra specialskolerne begynder på.

Tilsvarende viser tabellen, at betydeligt flere specialskoleelever er i gang med forberedende aktiviteter to år efter 9 . klasse (26 pct.) frem for et år efter (7 pct.). Endelig ses det af tabellen, at det stadig kun er en relativt beskeden andel af specialskoleeleverne (6 pct.), som to år efter afslutningen på 9. klasse hverken er i beskæftigelse eller i gang med et uddannelsesforløb. Resultatet er vigtigt, fordi det vidner om, at langt de fleste specialskoleelever ikke dropper ud af det uddannelsesvalg, som de påbegyndte i løbet af det første år efter afslutningen på 9. klasse - i hvert fald ikke til fordel for ledighed. Samtidig viser tabellen dog, at der to år efter 9. klasse er omkring 3 pct. af specialskoleeleverne, som i over tre måneder hverken har været i uddannelse, beskæftigelse eller får offentlig forsørgelse. Hermed er der altså en mindre gruppe af tidligere specialskoleelever, man bør være særligt opmærksomme på.

Sammenfattende viser tabellen, at langt de fleste specialskoleelever vælger at fortsætte i 10. klasse efter afslutningen af 9. klasse. I forhold til eleverne fra folkeskolens specialklasser er specialskoleeleverne længere om at begynde både på forberedende aktiviteter og på en egentlig ungdomsuddannelse. Til gengæld

\footnotetext{
${ }^{16}$ Det er p.t. kun 9. klasse-årgangen fra 2011, der kan følges i to år efter 9. klasse. Da oplysninger om undervisning i specialklasse først findes fra 2012, kan vi ikke særskilt se på status for elever fra specialklasser to år senere. Af samme årsag kan vi ikke inddrage elevernes uddannelses- og beskæftigelsesstatus to år senere som udfaldsmål i de efterfølgende regressionsanalyser.
} 
viser analyserne af specialskoleelevernes uddannelsesvalg to år efter færdiggørelsen af 9. klasse, at langt størstedelen af eleverne begynder på de forberedende aktiviteter eller kommer i gang med at tage en ungdomsuddannelse. I forlængelse af denne detaljerede beskrivelse af specialskoleelevernes uddannelsesvalg efter 9. klasse, undersøger vi i næste afsnit, om elevernes skolegang på en specialskole isoleret set kan siges at have betydning for deres valg af uddannelse.

\section{BETYDNING AF SKOLEGANG PÅ SPECIALSIKOLE FOR UDDANNELSESVALG}

Parallelt til afsnit 2.1 undersøger vi i dette afsnit betydningen af skolegang på en specialskole ved at tage højde for de samme baggrundsfaktorer blandt eleverne på henholdsvis specialskoler og i specialklasser.

For det første har vi undersøgt, om skolegang på en specialskole er forbundet med, om eleverne er i gang med en ungdomsuddannelse i slutningen af (skole)året efter afslutningen af 9 . klasse. Her viser analyserne både med og uden kontrolvariable, at der er statistisk sikker forskel på sandsynligheden for at være i gang med en ungdomsuddannelse mellem elever fra henholdsvis specialskoler og specialklasser, jf. tabel 2.6. Minustegnet viser, at sandsynligheden for at påbegynde en ungdomsuddannelse et år efter 9. klasse er lavere for specialskoleeleverne end for eleverne fra folkeskolens specialklasser. Som det ses af tabellen, forbliver forskellene mellem de to elevgrupper statistisk sikre, når der tages højde for de tidligere beskrevne baggrundsforhold ved eleverne. Hermed kan resultaterne tyde på, at specialskolegang betyder, at eleverne starter i mindre grad - eller i det mindste senere - på en ungdomsuddannelse, end hvis eleverne havde gået i en specialklasse. Selvom vi i analyserne tager højde for en række betydningsfulde baggrundsforhold ved eleverne, kan det imidlertid ikke afvises, at resultatet skyldes, at det ikke har været muligt at kontrollere for samtlige relevante forskelle mellem specialskole- og specialklasseeleverne.

- I gang med en (almindelig) ungdomsuddannelse

- I gang med en uddannelse (inkl. forberedende forløb + 10. kl.). 
Tabel 2.6. Betydningen af skolegang på specialskole for uddannelsesvalg efter 9. klasse.

\begin{tabular}{|l|c|c|}
\hline $\begin{array}{l}\text { I gang med en (almindelig) ungdomsuddannelse (vs. } \\
\text { anden uddannelse/ikke i uddannelse) }\end{array}$ & Uden kontrolvariabler & Med kontrolvariabler \\
\hline $\begin{array}{l}\text { I gang med en uddannelse (inkl. forberedende forløb } \\
+ \text { 10. kl.) }\end{array}$ & $\div$ & $\div$ \\
(vs. ikke i uddannelse) & & \\
\hline
\end{tabular}

Anm.: +/: betyder henholdsvis en positiv eller negativ sammenhæng, der er signifikant på min. et 5-procents niveau.

- betyder ingen sammenhæng.

Deltagelse: $\mathrm{N}=3080$

Kilde: Egne beregninger på baggrund af registerdata fra Danmarks Statistik.

I forlængelse af betydningen af specialskolegang for, at eleverne begynder på en ungdomsuddannelse, har vi for det andet undersøgt, om specialskolegang har betydning for elevernes uddannelsesvalg mere generelt. Konkret har vi i denne analyse undersøgt betydningen af specialskolegang for at være i uddannelse senest et år efter 9. klasse, hvor uddannelse både er defineret som værende (a) i ungdomsuddannelse, (b) i et 10. klasses forløb og (c) at deltage i forberedende aktiviteter. Ud fra denne bredere forståelse af uddannelse viser analyserne, at der hverken med eller uden kontrolvariable er statistisk sikker forskel på specialskole- og specialklasseelevernes uddannelsesvalg et år efter, at de har forladt 9. klasse. Resultatet tyder dermed på, at specialskoleelever ikke har forøget risiko for at droppe ud af uddannelsessystemet i året, der følger afslutningen af 9 . klasse.

\section{DISIKUSSION AF ANALYSERESULTATERNE}

I dette afsnit har vi undersøgt, hvordan det går eleverne før afslutningen på deres grundskoleforløb på en specialskole samt elevernes uddannelsesvalg umiddelbart efter 9. klasse.

Analyserne viser for det første, at specialskoleeleverne deltager sjældnere end eleverne i specialklasser i folkeskolens afgangsprøve. Forskellen forbliver desuden statistisk sikker, når vi tager højde for en række baggrundsfaktorer ved 
eleverne såsom henvisningsårsag og deres forældres sociale og økonomiske baggrund.

For det andet viser analyserne, at de - om end relativt få (29 \%) - specialskoleelever, som deltager i prøverne, klarer sig bedre end de elever fra specialklasser, der deltager. Analyserne med kontrolvariable viser imidlertid, at forskellene på de to elevgruppers præstationsniveau kan henføres til de baggrundsfaktorer, der tages højde for i disse analyser. På baggrund analyserne kan det således ikke konkluderes, at specialskoleelevernes faglige præstationer er højere end specialklasseelevernes, fordi de går på en specialskole. Forskellene skyldes snarere, at det er nogle andre typer af elever på specialskoler end i specialklasser, som deltager i prøverne.

Endvidere viser analyserne i dette afsnit, at svaret på spørgsmålet om, hvorvidt specialskolegang har betydning for elevernes uddannelsesvalg afhænger af, hvordan man definerer uddannelse. Anvendes en snæver forståelse af uddannelse - som værende påbegyndelse af en ungdomsuddannelse - viser analyserne, at specialskoleeleverne i mindre grad end specialklasseeleverne er i gang i slutningen af det første år efter 9. klasse. Omvendt finder vi ingen statistisk sikre forskelle mellem specialskole- og specialklasseelevernes uddannelsesvalg, når uddannelse defineres mere bredt som værende både en ungdomsuddannelse, et 10. klasse-forløb eller deltagelse i forberedende aktiviteter. Endvidere viser den detaljerede beskrivelse af specialskoleelevernes uddannelsesvalg, jf. tabel 2.5, at langt de fleste specialskoleelever (75 pct.) inden for to år efter afslutningen af 9. klasse enten er i gang med forberedende aktiviteter eller en ungdomsuddannelse. Dog er kun knap 20 pct. i gang med en almindelig ungdomsuddannelse, mens de øvrige 55 pct. enten er i gang med en såkaldt Særligt Tilrettelagt Ungdomsuddannelse (STU) eller forberedende aktiviteter. 


\section{3. 'DE 21-ÅRIGE' FEM ÅR EFTER GRUNDSKOLEN \\ Uddannelse, beskœftigelse, kriminalitet og helbred}

I forrige kapitel så vi på, hvordan specialskoleelever klarer sig fagligt ved afslutningen af skolegangen i 8./9. klasse, og hvilke uddannelsesvalg de træffer umiddelbart efter 9. klasse. I dette kapitel flytter vi fokus fem år, idet vi undersøger, hvordan det er gået tidligere specialskoleelever fem år efter, de gik ud af 9. klasse. Vi ser her på lidt ældre årgange, nemlig elever der afsluttede 9. klasse i årene 2002-2006. Helt konkret undersøger vi, om unge, der har haft deres skolegang på en specialskole, gennemsnitligt klarer sig dårligere som unge voksne i forhold til uddannelse og beskæftigelse, kriminalitet og helbred sammenlignet med unge med lignende opvækstvilkår, som ikke har gået på specialskole, men på en almindelig folkeskole (specialklasse).

Som i afsnit 2 anvender vi lineære regressionsmodeller for at sammenligne gruppen af tidligere specialskoleelever med lignende elever i folkeskolen fem år efter grundskolen. Som tidligere nævnt, ville vi helst kunne sammenligne med elever i specialklasser direkte, ligesom det er gjort i afsnit 3 for årgang 2012. For disse ældre generationer er der dog ikke data for undervisning i specialklasse, hvorfor vi må søge en relevant sammenligning på anden vis. Vi sammenligner derfor generelt med elever $\mathrm{i}$ folkeskoler, som har et lignende fagligt niveau i slutningen af 9. klasse som specialskoleeleverne (samt ligner mht. psykisk helbred og evt. anbringelse i slutningen af skolegangen). Målet er ved hjælp af disse kontroller - på trods af at vi ikke direkte kan identificere dem i vores data indirekte at sammenholde elever i specialskole med elever, der går i specialklasse. Som nævnt i afsnittet om metode skal resultaterne i dette afsnit fortolkes som den betydning, som undervisning i specialskole har på de anvendte ud- 
faldsmål, der ligger udover den betydning, det måtte have for elevernes resultater indtil slutningen af 9 . klasse.

\subsection{Uddannelse og beskœftigelse}

I forhold til ens muligheder på arbejdsmarkedet har gennemførelse af minimum en ungdomsuddannelse stor betydning. Selvom man som 21-årig ofte stadig er under uddannelse, inddrager vi uddannelsesperspektivet, da det kan give en fornemmelse af, hvor udviklingen bærer henad. Fra andre studier af hvordan elever med særlige behov klarer sig efter endt skolegang, ved vi, at disse unge har større risiko for at ende som lavt uddannede eller ufaglærte og er oftere arbejdsløse som voksne ${ }^{17}$.

Konkret forsøger vi i dette afsnit at komme tættere på den gennemsnitlige betydning af at gå i specialskole på følgende udfaldsmål, som vi måler fem år efter 9. klasse:

- Afsluttet ungdomsuddannelse eller er under uddannelse

- Under uddannelse/i beskæftigelse

- Modtagelse af kontanthjælp eller førtidspension.

I det følgende bekrives operationaliseringen af de tre resultatmål.

\section{MÅL FOR UDDANNELSE OG TILIKNYTNING TIL ARBEJDSMARIEDET}

I dette afsnit anvender vi registeroplysninger om højeste uddannelsesniveau, beskæftigelse, igangværende uddannelse ${ }^{18}$, kontanthjælp og førtidspension $\mathrm{i}$ analyserne for vores fem årgange af elever (2002-2006), som vi observerer fem

\footnotetext{
17 Currie \& Stabile, 2007; Fletcher \& Wolfe, 2008; Lichtenstein, 1987; McGee, 2011; Wagner \& Blackorby, 1996; Zigmond \& Thornton, 1985.

${ }^{18}$ Igangværende uddannelse omfatter stort set alle former for uddannelser, fx folkeskole, højskole, gymnasiale og tekniske uddannelser, AMU-uddannelser, professionshøjskoleuddannelser, universitetsuddannelser osv. I forhold til beskæftigelse anvendes Danmarks Statistiks variable socio og socio02, som er klassificeret på grundlag af den væsentligste beskæftigelse i løbet af året. I vores klassifikation kategoriseres man som ikke i beskæftigelse eller uden for arbejdsmarkedet, hvis man ikke er i gang med en uddannelse eller ikke er i en eller anden form for beskæftigelse.
} 
år efter, de har gået i 9. klasse. Vi måler således resultaterne med registeroplysninger fra årene 2007-2011.

Først og fremmest ser vi på, om de tidligere specialskoleelever er i et uddannelsesforløb som 21-årige og hvis ikke, om de alternativt er beskæftiget på arbejdsmarkedet eller på kontanthjælp/førtidspension. En typisk ung vil som 21årig være færdig med en ungdomsuddannelse og muligvis allerede være i gang med en videregående uddannelse. For elever fra specialskoler kan situationen være anderledes. De har måske gennemført en forberedende uddannelse og er måske nu i gang med en erhvervsuddannelse. Vi kan således ikke alene bruge højeste opnåede uddannelse som et retvisende billede af de unges uddannelsesmæssige situation, og vi skelner derfor også til igangværende uddannelse for sammen med den unges beskæftigelsesmæssige situation at få den bedst mulige indikation af, hvilken retning de unges liv har. Vi ser dermed samlet på to udfaldsmål: (i) om de unge enten er i beskæftigelse eller under uddannelse fem år efter 9. klasse, og (ii) om de unge enten har afsluttet en ungdomsuddannelse eller stadig er i gang med en uddannelse.

Det tredje udfaldsmål er, (iii) om man modtager kontanthjælp eller førtidspen$\operatorname{sion}^{19}$. Når man modtager af en af disse ydelser, befinder man sig nederst i samfundets sikkerhedsnet, hvilket både øger sandsynligheden for marginalisering på arbejdsmarkedet og medfører relativt lave forsørgelsesniveauer, som det som ung voksen kan være svært at komme ud af igen.

\section{ANALYSERESULTATER: SPECIALSKOLEELEVERNES UDDANNELSE OG BESKAFF- TIGELSE FEM ÅR EFTER 9. KLASSE}

Vi begynder med en beskrivelse af, hvordan det er gået specialskoleeleverne fem år efter, de har forladt 9. klasse. De tidligere specialskoleelever sammenlignes indledningsvis både med folkeskoleelever generelt og med elever i folkeskolen, der ikke er gået op til folkeskolens afgangsprøve ${ }^{20}$, jf. tabel 3.1.

\footnotetext{
${ }^{19}$ Konkret er kontanthjelp og førtidspension operationaliseret ved at se på, om man som 24-årig som minimum har modtaget disse ydelser i seks måneder i det pågældende år.

${ }^{20}$ Som udgangspunkt lader det til at være en god tilnærmelse, idet kun 13,5 pct. af specialskoleeleverne i disse elevårgange er gået op til afgangsprøven.
} 
Tabel 3.1. Uddannelse og tilknytning til arbejdsmarkedet for elever i 9. klasse i skoleårene 2001/02-2005/06.

\begin{tabular}{|c|c|c|c|c|}
\hline & $\begin{array}{l}\text { Elever i spe- } \\
\text { cialskoler }\end{array}$ & $\begin{array}{c}\text { Elever i } \\
\text { folkeskolen }\end{array}$ & $\begin{array}{l}\text { Forskel ml. elever- } \\
\text { ne i special- og } \\
\text { folkeskoler }\end{array}$ & $\begin{array}{l}\text { Elever i folkesko- } \\
\text { len, der ikke går op } \\
\text { til FSA }\end{array}$ \\
\hline \multicolumn{5}{|l|}{$\begin{array}{l}\text { Højeste fuldførte (kompetencegivende) } \\
\text { uddannelse }\end{array}$} \\
\hline Grundskole & $93 \%$ & $33 \%$ & & $81 \%$ \\
\hline Almene gymnasiale uddannelser & $1 \%$ & $38 \%$ & & $6 \%$ \\
\hline Erhvervsgymnasiale uddannelser & $<1 \%$ & $15 \%$ & & $3 \%$ \\
\hline Erhvervsfaglige, praktik og hovedforløb & $5 \%$ & $14 \%$ & & $11 \%$ \\
\hline Videregående uddannelser & $0 \%$ & $<1 \%$ & & $<1 \%$ \\
\hline Chi2-test & \multicolumn{2}{|c|}{$* * *$} & & \\
\hline \multicolumn{5}{|l|}{ Socioøkonomisk status } \\
\hline $\begin{array}{l}\text { Har afsluttet en ungdomsuddannelse } \\
\text { eller er under uddannelse fem år efter } \\
\text { 9. klasse. }\end{array}$ & $33 \%$ & $82 \%$ & $* * *$ & $45 \%$ \\
\hline Er i arbejde eller uddannelse & $42 \%$ & $89 \%$ & $* * *$ & $64 \%$ \\
\hline - Under uddannelse & $28 \%$ & $52 \%$ & $* * *$ & $32 \%$ \\
\hline - I arbejde & $14 \%$ & $37 \%$ & $* * *$ & $32 \%$ \\
\hline Ledige & $2 \%$ & $1 \%$ & $* *$ & $3 \%$ \\
\hline Modtager førtidspension & $38 \%$ & $0 \%$ & $* * *$ & $5 \%$ \\
\hline Modtager kontanthjælp & $15 \%$ & $3 \%$ & $* * *$ & $14 \%$ \\
\hline
\end{tabular}

Anm.: ${ }^{* * *} p<0,001,{ }^{* *} p<0,01$ og ${ }^{*} p<0,05$. T-test er anvendt, og stjernerne indikerer signifikante forskelle mellem eleverne $\mathrm{i}$ henholdsvis specialskoler og i folkeskolen.

Kilde: Egne beregninger på baggrund af registerdata fra Danmarks Statistik.

Af tabel 3.1 ses det, at der blandt de tidligere specialskoleelever er markant flere unge, der fem år efter 9. klasse ikke har afsluttet en ungdomsuddannelse eller i det mindste er under uddannelse. Det drejer sig om 93 pct., der har grundskolen som højeste kompetencegivende uddannelse sammenlignet med 33 pct. af de jævnaldrende i folkeskolen generelt og 81 pct. i gruppen af tidligere folkeskoleelever uden afgangsprøve. 
Med hensyn til de gymnasiale uddannelser ses, at næsten ingen specialskoleelever har studentereksamen fem år efter 9. klasse sammenlignet med over halvdelen af eleverne i folkeskolen generelt (38 pct. stx og 15 pct. hhx/htx). Til sammenligning har 9 pct. af folkeskoleeleverne uden afgangseksamen taget en gymnasial uddannelse.

Selvom 13 pct. er i gang med en erhvervsuddannelse i slutningen af andet år efter 9. klasse (jf. tabel 2.5), så har kun 5 pct. afsluttet en erhvervsuddannelse fem år efter 9. klasse ${ }^{21}$. Den ret høje andel elever, der er i gang med en STU efter to år, bidrager ikke til at øge andelen med en erhvervsuddannelse som højeste kompetencegivende uddannelse, idet STU ikke er en kompetencegivende uddannelse. Derfor vil unge, som har fuldført en STU, stå i registret med deres højeste fuldførte kompetencegivende uddannelse, hvilket i mange tilfælde kun vil være grundskolens 9. eller 10. klasse.

Endvidere ses det, at en væsentligt mindre andel af gruppen af tidligere specialskoleelever end den tilsvarende andel af gruppen af tidligere folkeskoleelever som helhed er i beskæftigelse eller under uddannelse fem år efter 9. klasse. Konkret drejer det sig samlet om godt 40 pct. af gruppen af specialskoleelever mod knapt 90 pct. af de tidligere folkeskoleelever som helhed. Blandt tidligere folkeskoleelever, som ikke har taget afgangsprøven, er det 64 pct., der er i beskæftigelse eller under uddannelse.

Hvad angår kontanthjælp og førtidspension, er der også markante forskelle. Andelen af tidligere specialskoleelever på førtidspension og kontanthjælp er 38 pct. hhv. 15 pct., hvor det er mindre end 1 pct. hhv. 3 pct. for folkeskoleelever som helhed, og 5 pct. og 14 pct. for folkeskoleelever uden afgangseksamen. De tidligere specialskoleelever skiller sig særligt ud mht. en markant større forekomst af førtidspensionsmodtagere i forhold til folkeskoleelever uden afgangseksamen, mens der ikke er forskel mht. risikoen for at være på kontanthjælp.

\footnotetext{
${ }^{21}$ Bemærk, at vi her sammenligner forskellige årgange af elever. Vi måler status to år efter 9. klasse på 2011-årgangen, mens status fem år efter måles på årgangene 2002-2006. Det betyder, at vi ikke entydigt kan konkludere, at den lave gennemførelsesprocent alene skyldes frafald fra en påbegyndt EUD.
} 
Alt $i$ alt ses det af tabel 3.1, at specialskoleelever til en vis grad ligner folkeskoleelever uden afgangseksamen mht. de fleste udfaldsmål, når man ser bort fra modtagelse af førtidspension, hvor specialskoleeleverne er markant overrepræsenterede. På baggrund af tallene i tabel 3.1 kan man ikke konkludere noget endegyldigt om de tidligere specialskoleelevers fremtidige tilknytning til arbejdsmarkedet. Umiddelbart indikerer tallene dog, at en stor del vil have vanskeligheder ved at komme til at kunne forsørge sig selv.

\section{BETYDNING AF SKOLEGANG PÅ SPECIALSKOLE FOR UDDANNELSE OG BE- SKÆFTIGELSE FEM ÅR SENERE}

De deskriptive analyser i det foregående afsnit peger på, at de tidligere specialskoleelever klarer sig dårligere i forhold til beskæftigelse og uddannelse end andre unge. Men hvorvidt det er en følge af, at de har gået på en specialskole, eller i stedet en følge af de forhold, der oprindeligt gav anledning til visitation til specialskole, siger resultaterne i sig selv ikke noget om. Derfor viser vi i dette afsnit resultaterne af vores regressionsanalyser for uddannelses- og beskæftigelsesmålene. Her fokuserer vi på, hvordan de tidligere specialskoleelever klarer sig i forhold til opnået ungdomsuddannelse/i gang med uddannelse, under uddannelse/i beskæftigelse, modtagelse af kontanthjælp/førtidspension, når de sammenlignes med folkeskoleelever, der ligner dem mht. en lang række karakteristika. 
Tabel 3.2. Betydningen af skolegang på specialskole for uddannelse og tilknytning til arbejdsmarkedet som 21-årig.

\begin{tabular}{|l|c|c|}
\hline Tidligere specialskoleelever som 21-årige & Uden kontrolvariabler & Med kontrolvariabler \\
\hline $\begin{array}{l}\text { Har ikke afsluttet en ungdomsuddannelse eller er i } \\
\text { uddannelse }\end{array}$ & + & + \\
\hline Er hverken i arbejde eller i uddannelse & + & + \\
\hline Modtager førtidspension eller kontanthjælp & + & + \\
\hline
\end{tabular}

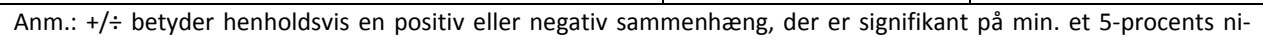
veau.

- betyder ingen sammenhæng.

$\mathrm{N}=219.720$ for "har ikke afsluttet en ungdomsuddannelse eller er i uddannelse".

$\mathrm{N}=219.239$ for "er hverken i arbejde eller i uddannelse" og "modtager førtidspension eller kontanthjælp". Kilde: Egne beregninger på baggrund af registerdata fra Danmarks Statistik.

Af tabel 3.2 fremgår regressionresultaterne for de tidligere specialskoleelever fem år efter 9. klasse. Vi finder en statistisk sikker sammenhæng mellem det at have haft sin skolegang i specialskole, og hvorvidt man har afsluttet en ungdomsuddannelse eller er under uddannelse fem år senere. Resultatet gælder uanset, om sammenhængen undersøges med eller uden kontrolvariable. Det vil sige, at tidligere specialskoleelever har øget risiko for at være kommet bagud mht. uddannelse.

Det er i denne sammenhæng værd at repetere, at vi i disse regressioner kontrollerer for elevernes karakteristika/resultater i slutningen af grundskolen. Der er således taget højde for forskelle i elevernes faglige resultater, et mål for psykisk helbred samt evt. anbringelse udenfor hjemmet. Det vil sige, at de her angivne resultater betyder, at specialskoleelever, der bl.a. har lignende faglige resultater $i$ slutningen af skolegangen, klarer sig dårligere end lignende elever fra folkeskolen (specialklasse).

I forhold til de andre to udfaldsmål findes lignende tendenser: tidligere specialskoleelever er mindre hyppigt $i$ arbejde eller uddannelse og modtager oftere overførselsindkomster i form af kontanthjælp eller førtidspension. 


\subsection{Kriminalitet og helbred}

I det foregående afsnit har vi set, at de tidligere specialskoleelever fem år efter 9. klasse klarer sig dårligere $\mathrm{i}$ forhold til uddannelse og beskæftigelse end de unge, som de sammenlignes med. I dette afsnit undersøger vi de to sidste udfaldsmål i denne undersøgelse: kriminalitet og sundhed. Spørgsmålet er, om de har en højere kriminalitetsrate og et dårligere helbred end de elever, de sammenlignes med, og om skolegangen på en specialskole har en selvstændig betydning for, hvordan de klarer sig?

Tidligere studier af elever med særlige behov viser, at indlæringsvanskeligheder ofte er forbundet med øget risiko for psykiske problemer ${ }^{22}$ og er relateret til øget kriminalitet ${ }^{23}$.

\section{MÅL FOR KRIMINALITET \& SUNDHED}

I dette afsnit er de registeroplysninger om kriminalitet og helbred, der eksisterer for vores 9. klasse-elevårgange fra 2002-2006 i 5 års perioden efter 9. klasse udgangspunktet for analyserne.

I analyserne af kriminalitet ser vi på følgende udfaldsmål i 5-års-perioden efter 9. klasse.:

- Ubetinget dom

- Mindst én dom (betinget eller ubetinget)

- Sigtelse.

I forhold til alle kriminalitetsudfald inkluderes domme og sigtelser indenfor straffeloven, loven om euforiserende stoffer samt våbenloven, men ikke færdselsloven eller skatte- og afgiftslove. Spørgsmålet er, om gruppen af tidligere specialskoleelever har større sandsynlighed for at have en dom eller sigtelse end kontrolgruppen.

\footnotetext{
22 Emerson \& Hatton, 2007; Dykens, 2000; Wallander et al., 2003; Einfeld \& Emerson, 2007

${ }^{23}$ Read, 2008; Read \& Read, 2008; Read \& Read, 2009.
} 
$\begin{array}{ll}48 & \text { SPECIALSKOLEELEVERS RESULTATER VED } \\ \text { SKOLEGANGENS AFSLUTNING OG FEM AR } \\ \text { SENERE }\end{array}$

Hvad angår helbred, måles det psykiske helbred på, i hvilken udstrækning de tidligere specialskoleelever har haft så alvorlig en psykisk sygdom, at de har været i kontakt med det psykiatriske system og dermed er registreret i det psykiatriske forskningsregister i 5-års-perioden efter 9. klasse. At være registreret i det psykiatriske forskningsregister betyder ikke nødvendigvis, at man har været indlagt - man kan også blive registreret, hvis man er på den psykiatriske skadestue. Det somatiske helbred måles på, om de unge er registreret med mindst én diagnose i Landspatientregistret i 5 års perioden efter 9. klasse.

I dette afsnit forsøger vi at undersøge betydningen af at gå i specialskole på følgende helbredsmål i 5-års-perioden efter 9. klasse:

- Mindst én diagnose i Landspatientsregistret (somatisk helbredsmål)

- Registrering i det psykiatriske forskningsregister (psykisk helbredsmål).

\section{ANALYSERESULTATER: SPECIALSIKOLEELEVERNES KRIMINALITET OG HELBRED FEM ÅR SENERE}

I forhold til alle fem udfaldsmål i dette afsnit ser vi på hele 5-års-perioden efter afslutning af 9 . klasse. I den simple fordeling af grupperne af unge fra årgangene 2002-2006 fordeler de sig som i tabel 3.3 i forhold til kriminalitet og helbred. Fordelingerne for de tidligere specialskoleelever og sammenligningsgruppen fra folkeskolen som helhed er markant forskellige, mens folkeskoleelever uden afgangsprøve ligner specialskoleelever ret meget, jf. tabel 3.3. Hvor omtrent 5 pct. af de tidligere specialskoleelever har fået en ubetinget dom, ca. 10 pct. mindst én dom og over 20 pct. en sigtelse både blandt specialskoleelever og folkeskoleelever uden afgangsprøve, så er disse udfald blandt folkeskoleelever som helhed med hhv. 1 pct., 4 pct. og 10 pct. markant mindre hyppige. 
Tabel 3.3. Elevernes kriminalitet og sundhed fem år efter afslutningen på 9. klasse.

\begin{tabular}{|c|c|c|c|c|}
\hline & $\begin{array}{l}\text { Elever i spe- } \\
\text { cialskoler }\end{array}$ & $\begin{array}{c}\text { Elever i } \\
\text { folkeskolen }\end{array}$ & $\begin{array}{l}\text { Forskel ml. elever- } \\
\text { ne i special- og } \\
\text { folkeskoler }\end{array}$ & $\begin{array}{c}\text { Elever i folkesko- } \\
\text { len, der ikke går op } \\
\text { til FSA }\end{array}$ \\
\hline \multicolumn{5}{|l|}{ Kriminalitet } \\
\hline Ubetinget dom & $5 \%$ & $1 \%$ & $* * *$ & $6 \%$ \\
\hline Min. én dom (betinget eller ubetinget) & $11 \%$ & $4 \%$ & $* * *$ & $12 \%$ \\
\hline Sigtelse & $22 \%$ & $10 \%$ & $* * *$ & $25 \%$ \\
\hline \multicolumn{5}{|l|}{ Sundhed } \\
\hline $\begin{array}{l}\text { Somatisk diagnose } 5 \text { år efter } 9 . \text { klasse } \\
\text { (landspatientregisteret) }\end{array}$ & $84 \%$ & $73 \%$ & $* * *$ & $80 \%$ \\
\hline $\begin{array}{l}\text { Psykiatrisk diagnose } 5 \text { år efter } 9 . \text { klasse } \\
\text { (psykiatriregistret) }\end{array}$ & $19 \%$ & $6 \%$ & $* * *$ & $15 \%$ \\
\hline
\end{tabular}

Anm.: *** $\mathrm{p}<0,001,{ }^{* *} \mathrm{p}<0,01$ og $* \mathrm{p}<0,05$. T-test er anvendt, og stjernerne indikerer signifikante forskelle mellem eleverne $i$ henholdsvis specialskoler og i folkeskolen.

Hver gang en person indlægges på et hospital eller modtager en ambulant behandling på et hospital, registreres personen $\mathrm{i}$ Landspatientregistret med en diagnose. Det betyder, at tilsyneladende raske personer ( $\mathrm{fx}$ en kvinde, der har født et raskt barn uden komplikationer) får tildelt en diagnose blot for at have været indlagt. Denne diagnosticering medfører, at andelen af en befolkning med en diagnose er relativ $h ø j$, set i forhold til befolkningens sygelighed.

Kilde: Egne beregninger på baggrund af registerdata fra Danmarks Statistik.

Af tabel 3.3 fremgår det, i hvilken udstrækning eleverne har haft så alvorlig en psykisk sygdom, at de har været i kontakt med det psykiatriske system og dermed er registreret $\mathrm{i}$ det psykiatriske forskningsregister i de fem år efter afslutningen af 9. klasse. Endvidere fremgår det, om eleverne har fået stillet en somatisk diagnose. Tidligere specialskoleelever har, hvad angår somatisk helbred, gennemsnitligt 11 procentpoint større sandsynlighed for at have været $\mathrm{i}$ kontakt med det somatiske hospitalssystem i 5-års-perioden efter 9. klasse end folkeskoleelever som helhed (84 pct. over for 73 pct.). Andelen for sammenligningsgruppen af folkeskoleelever uden afgangseksamen ligger lidt lavere end for specialskoleelever. Psykisk har specialskoleeleverne en markant oversygelighed sammenlignet med folkeskoleelever som helhed. 19 procent er registreret i det psykiatriske forskningsregister mod $6 \%$ af folkeskoleeleverne. Forskellen til folkeskoleelever uden afgangseksamen er dog mindre, da 15 pct. af disse er registreret i det psykiatriske forskningsregister). 


\section{BETYDNING AF SKOLEGANG PÅ SPECIALSKOLE FOR KRIMINALITET SAMT SOMATISK OG PSYKISK SUNDHED FEM ÅR SENERE}

De deskriptive analyser viser, at de tidligere specialskoleelever og folkeskoleelever uden afgangseksamen i højere grad er blevet dømt eller sigtet for kriminelle forhold og har ringere helbred end elever i folkeskolen som helhed. Om denne forskel fortsat består, når der via statistiske metoder tages højde for forskelle i elevernes baggrund samt psykisk helbred, anbringelse og faglige resultater i slutningen af grundskolen, ser vi på i det følgende. Ved at tage højde for disse forskelle elevgrupperne imellem sammenlignes tidligere specialskoleelever med en gruppe unge, der langt hen ad vejen er sammenlignelige.

Hvad angår både udfaldsmålene for kriminalitet og helbred, viser tabel 3.4, at der uden kontrolvariable er en sammenhæng mellem skolegang på specialskole og højere kriminalitetsrater samt dårligere helbredsmål sammenlignet med elever i folkeskolen som helhed. Sammenhængen forsvinder imidlertid i alle tilfælde, når vi i modellen med kontrolvariable tager højde for en række baggrundsforhold hos eleverne og status mht. fx de faglige evalueringer i 8./9. klasse. Forskellene i resultaterne henviser til, at vi har kontrolleret for en række faktorer, der både har betydning for elevernes kriminalitet og helbred fem år efter 9. klasse, og om eleverne har gået på specialskole eller folkeskole. Alt i alt finder vi således ikke nogen statistisk sikker sammenhæng mellem det at gå på specialskole og de unges helbred, samt om de har fået en dom i de første fem år efter grundskolen. Til gengæld har tidligere specialskoleelever mindre risiko for at blive sigtet for kriminalitet indenfor straffeloven, lov om euforiserende stoffer eller våbenloven end lignende unge, der har gået i folkeskolen. 
Tabel 3.4. Betydningen af skolegang på specialskole for kriminalitet og sundhed fem år efter afslutningen på 9. klasse.

\begin{tabular}{|c|c|c|}
\hline & Uden kontrolvariabler & Med kontrolvariabler \\
\hline Kriminalitet & + & - \\
\hline Ubetinget dom & + & - \\
\hline Min. én dom (betinget eller ubetinget) & + & - \\
\hline Sigtelse & + & $\div$ \\
\hline \multicolumn{3}{|l|}{ Sundhed } \\
\hline $\begin{array}{l}\text { Somatisk diagnose fem år efter } 9 . \text { klasse (landspati- } \\
\text { entregisteret) }\end{array}$ & + & - \\
\hline $\begin{array}{l}\text { Psykiatrisk diagnose fem år efter 9. klasse (psykiatri- } \\
\text { registret) }\end{array}$ & + & - \\
\hline \multicolumn{3}{|c|}{ 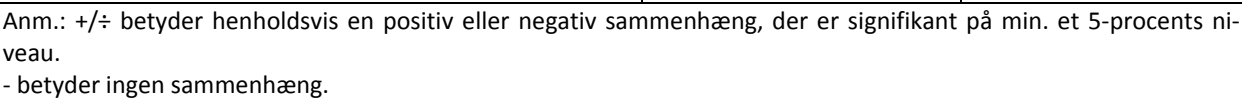 } \\
\hline
\end{tabular}

\section{DISIKUSSION AF ANALYSERESULTATERNE}

Sammenfattende peger resultaterne for skolegang i specialskole i dette afsnit på, at skolegang i specialskole hænger sammen med større social marginalisering, hvad angår uddannelse og beskæftigelse, når de unge er i starten af 20'erne, når man sammenligner med unge, der på alle observerbare variable ligner de tidligere specialskoleelever, men ikke selv har gået på specialskole. Det indikerer, at skolegang i specialskole som sådan kan forårsage et relativt dårligere udgangspunkt for deltagelse i ungdomsuddannelserne og på arbejdsmarkedet. Og den her fundne betydning af specialskolegang for resultater fem år senere ligger endog udover den påvirkning, som den har på elevernes status i slutningen af 9 . klasse, $\mathrm{fx}$ at de mindre ofte går op til FSA.

De indikatorer på social marginalisering og udstødelse, der er undersøgt, er, om de unge har afsluttet en ungdomsuddannelse, er under uddannelse/i arbejde, og om de modtager kontanthjælp eller førtidspension. Til gengæld er de tidligere specialskoleelever $i k k e$ ringere stillet, hvad angår kriminalitet og helbred. 
På baggrund af analyseresultaterne kan det dog ikke endegyldigt konkluderes, at skolegang i specialskole i sig selv stiller de unge dårligere i forhold til uddannelse og arbejdsmarked. Dette fordi vi ikke kan være helt sikre på, at de tidligere specialskoleelever har nøjagtig det samme udgangspunkt som de folkeskoleelever, de sammenlignes med. I de eksisterende registerdata mangler der væsentlige oplysninger, ikke mindst præcise oplysninger om børnenes egen problemprofil. Der foregår muligvis en selektionsproces i forbindelse med henvisning af elever til specialskoler, hvor kriterierne for selektionen kun delvis er kendte. Vores udgangspunkt er dog betydeligt bedre end mange andre analysers, idet vi både har oplysninger om henvisningsårsag til specialundervisning, hvilket er en proxy for barnets problemprofil, og for registrering i det psykiatriske forskningsregister.

Vi må således konstatere, at resultaterne - med de nævnte forbehold in mente peger på en sammenhæng mellem skolegang på specialskole og forøget social marginalisering, specielt hvad angår modtagelse af førtidspension fem år efter 9. klasse. 


\section{SAMMENFATNING OG KONIKLUSION}

Formålet med denne undersøgelse er at analysere både kort- og langtidsresultater af en skolegang på specialskole ved at sammenligne en række udfaldsmål hos specialskoleelever med ellers lignende elever, der har gået på folkeskole (specialklasse). Ved korttidseffekter af skolegang på specialskole forstår vi udviklingsudfald, der måles ved afslutningen af grundskoletiden: i denne undersøgelse i 8. og 9. klasse samt året efter 9. klasse. Ved langtidseffekter forstår vi udviklingsudfald, der måles fem år efter 9. klasse.

Der er flere mulige mekanismer, gennem hvilke skolegang på specialskole kan tænkes at påvirke de unges resultater, når man sammenligner med skolegang $\mathrm{i}$ en specialklasse. Helt basalt kan kvalitetsforskelle i undervisningstilbuddet spille en rolle, men lavere forventninger fra lærere, uddannelsesvejledere og potentielle arbejdsgivere kan også spille ind. Endvidere kan en skolegang på specialskole på de unges CV i sig selv have en stigmatiserende effekt og dermed være en hindringfor at finde fodfæste i ungdomsuddannelserne og på arbejdsmarkedet.

Der er mange og komplekse forhold, der præger unges udvikling. I denne undersøgelse har det dog været ambitionen særskilt at se på skolegangens påvirkning for de unges resultater. De områder af unges udvikling, der er fokuseret på i denne undersøgelse, er:

- Deltagelse i og resultater ved faglige evalueringer (nationale test, folkeskolens afgangsprøve)

- Uddannelsesvalg efter 9. klasse

- Uddannelse og arbejdsmarkedsdeltagelse fem år efter grundskolen

- Kriminalitet og helbred fem år efter grundskolen.

Undersøgelsen bygger på registerdata med en lang række oplysninger om eleverne og deres baggrundsforhold samt elevernes resultater. 
Overordnet set peger korttidsresultaterne af undersøgelsen på en lavere deltagelse blandt specialskoleelever ved folkeskolens afgangsprøve samt en lavere andel, der overgår til almindelige (ungdoms-)uddannelser direkte efter 9. klasse. Til gengæld er der ikke forskel på deltagelse i de nationale test eller karakterer og testscorer for dem, der deltager. Specialskoleelever fastholdes også i lige høj grad i uddannelsessystemet i året efter 9. klasse som deres jævnaldrende i specialklasser.

Langtidsresultaterne peger på, at tidligere specialskoleelever ikke har dårligere udfaldsmål mht. kriminalitet og helbred. Til gengæld er der markant forskel mht. social marginalisering, idet tidligere specialskoleelever har større risiko for at være sakket bagud mht. uddannelse fem år efter grundskolen og har særligt forøget risiko for at modtage førtidspension. Man kunne antage, at dette skyldes elever, der er på specialskole på grund af alvorlige medfødte lidelser eller handicap.

Et forskningsmetodisk problem i undersøgelser som denne er selektionsbias, som gør det svært at sammenligne specialskoleelever med en gruppe af elever i folkeskolen, og hvor de to grupper ellers er "fuldstændigt ens" - bortset fra om de går i specialskole eller specialklasse. Selvom man anvender statistiske metoder, der langt hen ad vejen kan reducere forskelle mellem de to grupper, kan man ikke gøre det så fuldstændigt, at usikkerheden om årsagsforhold forsvinder helt. I forhold til andre undersøgelser har vi dog særdeles nyttige baggrundsoplysninger til rådighed såsom henvisningsårsag til specialundervisning og registrering i det psykiatriske forskningsregister.

Alt i alt peger resultaterne i undersøgelsen på, at specialskoleelevers problemer hovedsageligt opstår i transitionsfasen fra det (beskyttede) skoleliv på specialskole. Det lader til, at de særligt har problemer med at skabe sig et voksenliv med uddannelse og en fast plads på arbejdsmarkedet, hvilket tyder på, at det er overgangen fra grundskolen til ungdomsuddannelserne og arbejdsmarkedet, der hovedsageligt volder problemer. 
I denne undersøgelse har vi estimeret den samlede betydning af skolegang på specialskoler og elevernes resultater. Man kan dog ikke sige, hvor stor en del af denne sammenhæng der skyldes hhv. kvalitet i uddannelse, stigmatisering/diskrimination af tidligere specialskoleelever i uddannelserne, på arbejdsmarkedet og i det sociale system - eller at gruppen af specialskoleelever i gennemsnit alligevel har særlige behov i et større omfang, end vi kan måle det med de forhåndenværende data. 


\section{REFERENCER}

Andersen, S.C. \& Winter, S.C. (2011). Ledelse, læring og trivsel i folkeskolerne. Kobenhavn, SFI.

Currie, J., \& Stabile, M. (2007). Mental health in childhood and human capital. NBER Working Paper 13217

Dykens, E. M. (2000). Psychopathology in children with intellectual disability. Journal of Child Psychology and Psychiatry, 41, 407-417.

Einfeld, S. \& Emerson, E. (2007). Intellectual disability. In Rutter's Child and Adolescent Psychiatry (eds M. Rutter, D. Bishop, D. Pine, et al, in press). Blackwell.

Emerson, E. \& C. Hatton (2007): Mental health of children and adolescents with intellectual disabilities in Britain The British Journal of Psychiatry (2007) 191: 493-499

Fletcher, J. \& Wolfe, B. (2008). Child mental health and human capital accumulation: The case of ADHD revisited, Journal of Health Economics, Elsevier, vol. 27(3), pages 794-800, May.

Hanushek, E. A., J. F. Kain \& S. G. Rivkin (2002). Inferring Program Effects for Specialized Populations: Does Special Education Raise Achievement for Students with Disabilities? Review of Economics and Statistics, 84: 584-599.

Keslair, F., E. Maurin \& S. McNally: Every child matters? An evaluation of "Special Educational Needs" programmes in England. Economics of Education Review Volume 31, Issue 6, December 2012, Pages 932-948.

Lichtenstein, S. (1987). Transition issues: Post-school employment patterns of handicapped and non-handicapped graduates and dropouts. Concord, $\mathrm{NH}$ : Office for Training and Educational Innovation.

McGee (2011). Skills, standards, and disabilities: How youth with learning disabilities fare in high school and beyond Economics of Education Review. Volume (Year): 30 (2011) Issue (Month): 1 (February) Pages: 109-129.

Rangvid, B.S. \& Egelund, N. (2014): Faktorer af betydning for kvalitet i specialskoler. En survey-kortlægning blandt specialskoler og PPR. SFI. 
Read, Fiona and Read, Elspeth (2008). Learning Disability and Serious Crime - Arson. Mental Health and Learning Disabilities Research and Practice, 5 (2). pp. 210-223.

Read, Stephen (2008). Learning Disabilities \& Serious Crime: Murder. Mental Health and Learning Disabilities Research and Practice, 5 (1). pp. 63-76.

Read, Fiona and Read, Elspeth (2009). Learning Disabilities and Serious Crime Sex Offences. Mental Health and Learning Disabilities Research and Practice, 6 (1). pp. 37-51

Wagner, M. M., \& Blackorby, J. (1996). Transition from high school to Work or College: How special education students fare. The Future of Children, 6, 103120.

Wallander, J. L., Dekker, M. C. \& Koot, H. M. (2003). Psychopathology in children and adolescents with intellectual disability: measurement, prevalence, course, and risk. In International Review of Research in Mental Retardation (ed. L. Glidden), pp. 93-134. Elsevier.

Zigmond, N., \& Thornton, H. (1985). Follow-up of post-secondary age learning disabled graduates and dropouts. Learning Disabilities Research, 1, 50-55. 




